\title{
Murteiden tutkimus väitöskirjojen viitteiden valossa
}

\author{
LotTa AARIKKA
}

\section{Johdanto}

Fennistisen murteentutkimuksen painopiste on siirtynyt kansallisesta, kielihistoriaan orientoituneesta tutkimuksesta (ks. esim. Aminoff 1871) kohti moninaista sosiolingvististä puhutun kielen tutkimusta (ks. esim. Priiki 2017). Dialektologian ja sosiolingvistiikan suhdetta ja tieteellistä paradigmanvaihdosta on käsitelty tieteenalalla runsaasti, erityisesti 1980-luvulla (esim. Siitonen 1981; Nuolijärvi 1986; Juusela 1994). Sen sijaan se, mikä yhdistää vanhaa tutkimusperinnettä nykyiseen alueellisen vaihtelun tutkimukseen, ei ole ollut tarkastelun keskiössä. Vähintäänkin voi sanoa, että tieteenalan kaanonia ei ole tarkasteltu kokonaisuutena määrälliseen aineistolähtöiseen analyysiin perustuvasta näkökulmasta.

Tässä artikkelissa tarkastelen suomalaisen murteentutkimuksen historiaa suomen kielen alalla ilmestyneiden murteita käsittelevien väitöskirjojen lähdeluetteloiden ${ }^{1}$ avulla. Tutkin bibliografisesta näkökulmasta, millainen tieteenalan kaanon on: keihin ja mihin teoksiin murteita käsittelevissä väitöskirjoissa viitataan. Luvussa 2 pureudun tarkemmin dialektologian ja sosiolingvistiikan suhteeseen sekä siihen, miksi tutkimusalaa on tarpeen tarkastella kokonaisuutena. Luvussa 3 esittelen, miten fennistiikan tutkimus- ja aatehistoriaa on aikaisemmin tutkittu ja miten oma lähestymistapani - väitöskirjojen lähteiden kvantitatiivinen analyysi - täydentää tutkimushistoriallista ymmärrystä. Luvussa 4 erittelen, mitkä väitöskirjat olen rajannut murteita käsitteleviksi, ja esittelen yleisesti kyseisten väitöskirjojen taustatietoja, kuten julkaisuvuosia ja ilmestymisyliopistoja. Luvussa 5 kerron artikkelini aineistosta eli 41 väitöskirjan lähdeluetteloista koostetusta lähdetietokannasta. Luvussa 6 analysoin lähdetietokantaa ja osoitan, mitkä ovat fennistisen murteentutkimuksen tutkimushistorian kannalta keskeiset teokset ja toisaalta keskeisimmät tutkijat. Näiden löydösten lisäksi esitän lähdetietokantadatan tekijätietoihin ja väitöskirjojen lähteiden julkaisuvuosiin perustuvan poikkileikkauksen tieteenalan kehityksestä. Luvussa 7 tiivistän, miten lähdeluetteloiden muodostaman lähdetietokannan avulla on mahdollista saada kokonaiskäsitys tutkimusalasta ja sen kehityksestä ja mitä kysymyksiä tämän tietokannan avulla on mahdollista tutkimushistorialle edelleen esittää.

1. Lähdeluettelolla tarkoitan tässä artikkelissa kirjallisuuslähteiden luetteloa ja lähteellä kirjallisuuslähdettä (vrt. aineslähdeluettelo, aineslähteet). 


\section{Dialektologian ja sosiolingvistiikan suhde fennistiikassa}

Fennistiikan eriydyttyä suomalais-ugrilaisten kielten tutkimuksesta puhutun kielen alueelliseen vaihteluun erikoistuneet tutkijat syventyivät äänteellisten erojen historian selvittämiseen. Toisin sanoen varhainen murteentutkimus ei keskittynyt kielelliseen vaihteluun yksilön ja idiolektin näkökulmasta vaan fokusoitui hahmottelemaan yhtenäisiä kielimuotoja ja selvittämään yksittäisten kielenpiirteiden ja niiden varianttien leviämistä ja levinneisyyttä. (Häkkinen 2008: 147-148.) 1800-luvun lopun ja 1900-luvun alun murteita tutkivia kielitieteilijöitä kiinnosti siis puhutun kielen historia, ja heidän näkökulmansa oli retrospektiivinen: informanteiksi valittiin vanhoja ja kouluttamattomia ihmisiä, jotka "osasivat" vanhaa murretta (Kurki 2007: 144-145; ks. esim. Virtaranta 1946: 7). Tutkimuskohde haluttiin kuvata ehyenä, vaikka tutkijat tunnistivat kielellisen vaihtelun olemassaolon. Informanttien puheen vaihtelua saatettiin merkitä muistiin, mutta sitä ei tehty systemaattisesti, sillä se ei ollut tutkijoiden fokuksessa - ennemminkin tutkimuksen tiellä (ks. esim. Kettunen 1930a: Alkusanat). Kielen muutos kuitenkin havaittiin ja siitä tehtiin huomioita (Mielikäinen 1980: 3). Osittain tieteenalan painopisteen valikoitumiseen ovat vaikuttaneet myös tutkimuksen tekniset apuvälineet eli se, miten kieltä on milloinkin ollut mahdollista tutkia (Juusela 1994: 2).

Tieteenala kohtasi paradigman murroksen, kun William Labov tutki New Yorkissa puhutun englannin äänteellistä vaihtelua. Labov osoitti, että muun muassa kielenkäyttäjän sosiaalinen tausta vaikuttaa hänen kielenkäyttöönsä (ks. esim. 1972, 2006). Labovin tutkimuksesta raportoi Suomessa Heikki Paunonen (1971), joka myöhemmin kertoi pioneerimaisen kirja-arvostelunsa kirjoittamisen olleen suoranainen sattuma (Paunonen 2009: 557). Tämä kansainvälisen tutkimuksen painopisteen muutos ja ympäröivä yhteiskunnallinen rakennemuutos eli kaupungistuminen johtivat siihen, että myös Suomessa katseet käännettiin kylien lisäksi kaupunkialueilla puhuttaviin kielimuotoihin. Vuosina 1976-1980 olikin käynnissä merkittävä valtakunnallinen, Suomen Akatemian rahoittama suomalaisen alueellisen ja sosiaalisen vaihtelun tutkimusprojekti Nykysuomalaisen puhekielen murros. Projektissa tutkittiin nimensä mukaisesti nykysuomalaista puhekieltä neljässä kaupungissa - Helsingissä, Jyväskylässä, Tampereella ja Turussa - hieman eri painotuksin. (Mielikäinen 1980: 19-21; Kurki 2007: 148-149.)

Kuten kaupunkikielien tutkimushankkeen nimi ("puhekielen murros") paljastaa, ennen kaupungistumisen aikaa tutkijoiden hypoteesi oli pitkälti se, että kaupungistumisen mukanaan tuoma lisääntynyt heterogeeninen vuorovaikutus "tasoittaa" sekä yksilön murteellisuuden että murteet kielimuotoina (esim. Rapola 1947: 8-9). Tuo hypoteesi on osoittautunut virheelliseksi. Vaikka joissain piirteissä niin kutsutut yleiskieliset variantit $^{2}$ ovat vallanneet alaa, murteet eivät ole kadonneet - eivät kielimuotoina eivätkä alueellisesti vaihtelevana aineksena kielenkäyttäjien puhekielestä (ks. esim. Mustanoja 2011: 370-373; Nuolijärvi 1986: 308-312). Siitä huolimatta tutkijoiden piirissä on tavanomaista puhua vanhojen murteiden tasoittumisesta ja muuttumisesta

2. Yleiskielinen variantti ei ole yksiselitteinen käsite. Esimerkiksi yleiskieliseksi mielletty hän yksikön 3. persoonan varianttina voidaan myös määritellä murteelliseksi (Priiki 2017: 9). (Ks. tarkemmin esim. Nuolijärvi \& Sorjonen 2005: 16.) 
aluepuhekieliksi (ks. esim. Tieteen termipankki 10.8.2016: Kielitiede:aluepuhekieli; Mielikäinen 1980: 22).

Seppo Knuuttila kirjoittaa teoksessaan Tyhmän kansan teoria (1994) teoreettisesta presentismistä sekä traditionalismista historianfilosofisina käsitteinä. Siinä, missä presentismi korostaa entisen ja nykyisen välistä katkosta ja sitä, miten mennyttä tulkitaan nykyhetken kontekstien ja käsitteiden avulla, traditionalistinen lähestymistapa näkee nykyhetken menneen tuotoksena (mts. 20-21). ${ }^{3}$ Näkökulma soveltuu erityisesti tutkimushistorian tarkasteluun: kielen voi kulttuurin tavoin nähdä joko jatkumona, jossa tutkimusaineistot ovat tilannekuvia alati vaihtelevasta ja muuttuvasta mutta samalla suhteessa menneeseen olevasta ilmiöstä (vaihteleva ja muuttuva puhekieli), tai nykyhetkestä havainnoituna jatkumona, jossa esiintyvillä jaksoilla on alku ja loppu (vanha murre - aluepuhekieli/nykypuhekieli). Kielen muuttuminen nähdään siis tieteenalan sisällä samaan aikaan sekä kielelle ominaisena, jatkumomaisena ilmiönä että eriytettynä tapahtumana, mitä kuvastaa parhaiten muutos terminologiassa: alueellisten kielimuotojen nimitykseen käytetty termi murre on korvautunut tai saanut rinnalleen uuden termin, aluepuhekielen tai nykypuhekielen. Tämä terminologinen eronteko tehdään useimmiten sen tarkemmin erittelemättä sitä, missä vaiheessa siirtyminen vanhasta murteesta uuteen aluepuhekieleen on tapahtunut ja millä tämän oletetun siirtymän ajoittamisen voisi perustella.

Koska motiivit tutkia puhuttua kieltä ja sen alueellisesti vaihtelevia muotoja ovat muuttuneet ratkaisevasti, on oleellista kysyä, miten tutkimuskohde on käsitteellisesti muuttunut ja miten tutkimuskohde on näyttäytynyt erilaisena sen perusteella, millaisia kysymyksiä sille on esitetty. Toisin sanoen murteen käsite on muuttunut ajan kuluessa, sillä tutkijat ovat esittäneet erilaisia kysymyksiä ja tutkineet puhuttua kieltä ja sen alueellista vaihtelua erilaisin teoreettisin viitekehyksin, aineistonkeruutavoin ja analyysimetodein.

Jotta on mahdollista tehdä tutkimushistorian pohjalta kriittinen käsiteanalyysi tutkimuskohteen muutoksesta, on aluksi selvitettävä, mikä on perusteltu ja kattava otos niin sanottua keskeistä tutkimushistoriaa. Tämän artikkelin motivaatio on siis bibliografisen analyysin avulla selvittää, keihin tutkijoihin on viitattu ja mitä nimikkeitä on käytetty eniten tieteenalan väitöstutkimuksien kirjallisina lähteinä. Artikkelissani keskiössä oleva kvantitatiivinen tutkimus mahdollistaa myöhemmin myös laadullisen tarkastelun.

\section{Miten fennistiikan tutkimushistoriaa ja väitöskirjoja on tutkittu?}

Fennistiikan tutkimushistoriaa on tutkittu lähes niin kauan kuin koko tieteenala on ollut olemassa. Yksi fennistiikan ja osittain fennougristiikankin historian yleistajuisista

3. Myös synkronia ja diakronia olisivat tässä yhteydessä käyttökelpoisia termejä, sillä ne hahmottavat tutkittavan ilmiön (kieli) suhdetta aikaan. Olen kuitenkin päätynyt käyttämään termejä traditionalismi ja presentismi, sillä ne ovat historianfilosofisia termejä, jotka hahmottavat ihmisten (tässä tapauksessa tutkijoiden) näkökulmaa ilmiöön suhteutettuna aikaan ja kuvaavat siksi paremmin tutkimukseni kohdetta, joka ei ole suoranaisesti kieli vaan tutkimushistoria. 
perusoppaista on Kaisa Häkkisen (2008) Suomen kielen historia 2, jossa on esitelty muitakin nimenomaan fennistiikan historiaan keskittyviä kysymyksiä (mts. 17-23). Myös Mikko Korhonen (1986) on kirjoittanut kattavan selvityksen fennistiikan ja fennougristiikan alkutaipaleesta. Yleisemmin kielitieteen historiaa on käsitelty pohjoismaisessa kontekstissa teoksessa The history of linguistics in the Nordic countries (Hovdhaugen, Karlsson, Henriksen \& Sigurd 2000).

Tutkimushistoriaa on mahdollista tarkastella monesta näkökulmasta. Fennistiikan historiasta on tutkittu esimerkiksi oppituoleja (esim. Suutari \& Salo toim. 2001), tieteenalalle keskeisiä henkilöitä (esim. Karlsson 200o), tieteenalan klassikoita (esim. Haddington \& Sivonen toim. 2010) ja tieteellisiä paradigmoja (esim. Kelomäki 2009) sekä niiden vaihdoksia (esim. Siitonen 1981). Myös teema - esimerkiksi kirjakielen kehitykseen liittyvät vaiheet - on tapa jäsentää tutkimuksen historiaa (esim. Huumo, Laitinen \& Paloposki toim. 2004).

Oma käsittelytapani yhdistelee edellä mainittuja näkökulmia uudella tavalla. Ensinnäkin lähestyn tutkimushistoriaa temaattisesti käsitellessäni nimenomaan murteiden tutkimuksen historiaa. Toiseksi käsittelen fennistiikan väitöskirjoja, jotka instituutiona vertautuvat alan oppituoleihin. Kolmanneksi tarkastelen, mitkä teokset ovat kvantitatiivisen, lähdeluetteloihin perustuvan empiirisen analyysin perusteella tieteenalalle keskeisiä ja ketkä ovat kirjoittaneet nuo teokset. Tarkasteluni poikkeaa siis pikemmin metodien kuin näkökulman perusteella aikaisemmasta tutkimuksesta. Lukuun ottamatta sitä, mitkä väitöskirjat lasketaan murteita käsitteleviksi väitöskirjoiksi, aineiston rajaukseni ei sisällä etukäteen tehtyä laadullista valintaa tai oletusta siitä, mitkä tutkimukset ja tutkijat ovat tieteenalalle keskeisiä. Sekä teokset että niiden tekijät nousevat lähdetietokantaaineistoni määrällisestä analyysista. Tämän artikkelin lopussa pyrin myös tuomaan esille, miltä osin kvantitatiivinen tulokulma tuottaa uutta tietoa ja miltä osin se vastaa yleistä oppihistorianäkemystä tieteenalan keskeisistä tutkijoista ja teoksista.

Fennistiikan väitöskirjoja on systemaattisesti listannut ja tarkastellut esimerkiksi Fred Karlsson (1998). Karlssonin bibliografia kielitieteen alalla julkaistuista väitöskirjoista sisältää jonkin verran määrälliseen analyysiin perustuvia empiirisiä havaintoja tieteenalan kehityksestä. Tarkemmin nimenomaan fennistiikan väitöskirjoja on tutkinut määrällisesti Pentti Leino (1992), joka tarkastelee artikkelissaan fennistiikan väitöskirjoja vuodesta 1960 vuoteen 1992. Leinon ajallinen rajaus on lyhyempi kuin Karlssonin ja minun, mutta hän on laskenut otokseensa myös ulkomaisissa yliopistoissa väitelleiden väitöskirjoja. Vaikka Leino keskittyy tarkastelussaan muun muassa väitelleiden sukupuoleen ja opintoihin kulutettuun aikaan, hän jaottelee artikkelissaan väitöskirjaotosta myös temaattisesti. Hän jakaa väitöskirjojen aihepiirit seitsemään kategoriaan, jotka ovat fonologia, morfologia, syntaksi, semantiikka, sanasto, nimistö ja muu. Näiden lisäksi Leino tarkastelee väitöskirjoja niiden aineiston perusteella. Aineistokategorioita hänen jaottelussaan on neljä: murteet, itämerensuomi, vanha kirjakieli ja nykysuomi. Kategoriajakoa hän perustelee yksinkertaisesti "kielitieteen perinteisellä jakautumisella" mutta huomauttaa "ryhmittelyn olevan joissakin tapauksissa väkinäistä" (mas. 15).

Myös tämän artikkelin aineistonrajauksessa olivat läsnä ryhmittelyn väkinäisyys sekä vaikeus yksiselitteisesti eritellä, mikä on murteita käsittelevä väitöskirja ja mikä 
ei (ks. lukua 4). Leinon jaottelussa on tämän artikkelin motivaation kannalta erityisen kiinnostavaa se, miten hän erottelee aineistokategorioissaan murteen ja nykysuomen. Myös tämä indikoi, että vaikka alueellista vaihtelua tutkitaan yhä ja alueellinen variaatio on edelleen läsnä uusissa puhutun kielen aineistoissa, on olemassa jokin eksplikoimaton syy, miksi murteet ja nykysuomi koetaan tarpeelliseksi käsitteellisesti erottaa toisistaan. Samankaltainen eronteko näkyy aineslähteideni eli väitöskirjojen (ks. taulukkoa 1 seur. sivulla) otsikoissa: alueelliseen kielimuotoon viittaava termi murre saattaa saada määreen vanha (väitöskirja 48 [2016]) tai korvautua termillä puhekieli (väitöskirja 46 [2011]) tai nykypuhekieli (väitöskirja 49 [2017]).

Lähdeluetteloiden ja sitaatioiden tarkasteleminen kvantitatiivisesta näkökulmasta on bibliometriikaksi kutsutun analyysin haara (Karlsson 1994: 5). Suomalaista kielitiedettä ei ole tutkittu bibliometrisestä näkökulmasta laajemmin, mutta Karlsson on tarkastellut vuonna 1994 ilmestyneessä julkaisussaan paitsi kielitieteen sitaatiotilastoja yleisesti (Arts and Humanities Citation Index) myös Virittäjässä 1/1981-1/1993 ilmestyneiden artikkelien lähdeluetteloita. Karlsson (mts. 15) toteaa, että hänen sitaatioanalyysinsa tuloksia voisi verrata suomen kielen väitöskirjojen kirjallisuuslähdetietoihin mutta että se ei ole nykykontekstissa mahdollista.

Tässä artikkelissa lähestyn fennististä tutkimushistoriaa nimenomaan väitöskirjojen lähteiden kvantitatiivisen analyysin avulla. En siis tarkastele yksin väitöskirjoja (luku 4) vaan myös niiden lähteitä (luvut 5-6). Pyrin näin ollen syventämään kvantitatiivisen tarkastelun laadullisuutta selvittäessäni, millainen on fennistisen murteentutkimuksen tutkimushistoria.

\section{Murteita käsittelevät väitöskirjat}

Rajatakseni tutkimusaineistoni perustellusti selvitin kaikki suomen kielen alalla ${ }^{4}$ vuosina 1840-2017 ilmestyneet väitöskirjat. Käytin selvitystyössäni apuna Karlssonin vuonna 1998 ilmestynyttä bibliografiaa Kielitieteiden tohtorinväitöskirjat Suomessa 1840-1997. Lisäksi lähetin tietopyynnöt Suomen kaikkien yliopistojen suomen kielen oppiaineisiin selvittääkseni Karlssonin tarkastelujakson jälkeen julkaistut väitöskirjat. Tietopyyntöjen avulla kartoitin siis vuoden 1997 syyslukukaudesta vuoden 2017 kevätlukukauteen mennessä ilmestyneet suomen kielen väitöskirjat. Näistä väitöskirjoista rajasin 50 väitöskirjan joukon (ks. taulukkoa 1). Rajauksessa käytin seuraavia kriteerejä:

1. Väitöskirjan nimessä esiintyy sana murre.

2. Väitöskirjan ensisijainen tutkimuskohde on murre tai murteiden väliset erot.

3. Väitöskirjan aineisto on pääasiassa murreaineistoksi nimettyä puhutun kielen aineistoa.

4. Väitöskirja ei käsittele yksinomaan nimistöä.

4. Käsite suomen kielen ala ei ole yksiselitteinen. Esimerkiksi aineistossani olevan Riikka Ylitalon väitöskirjan (2009) voisi katsoa kuuluvan ensisijaisesti fonetiikan alaan, mutta sen kansilehdellä mainitaan sekä fonetiikka että suomen kieli. 
Taulukko 1.

50 suomen kielen murteita tutkivaa tai pääasiassa murreaineistoon perustuvaa väitöskirjaa. HY = Helsingin yliopisto, ISY = Itä-Suomen yliopisto, JoY = Joensuun yliopisto, $J Y=$ Jyväskylän yliopisto, $\mathrm{OY}=$ Oulun yliopisto, $\mathrm{TaY}=$ Tampereen yliopisto, $\mathrm{TY}=$ Turun yliopisto, ÅA = Åbo Akademi.

\begin{tabular}{|c|c|c|c|c|}
\hline Tunniste & Tekijä & Nimike & Vuosi & Yliopisto \\
\hline 0 & Aminoff, Torsten & $\begin{array}{l}\text { Etelä-Pohjanmaan kielimurteesta } \\
\text { tutkimus }\end{array}$ & 1871 & $\mathrm{HY}$ \\
\hline 1 & Genetz, Arvid & $\begin{array}{l}\text { Lautphysiologische Einführung in } \\
\text { das Studium der vestfinnischen } \\
\text { Sprachen mit besonderer Berück- } \\
\text { sichtigung des Karelischen }\end{array}$ & 1877 & $\mathrm{HY}$ \\
\hline 2 & Porkka, Volmari & $\begin{array}{l}\text { Über den ingrischen Dialekt mit } \\
\text { Berücksichtigung der übrigen } \\
\text { finnisch-ingermanländischen Dialekte }\end{array}$ & 1885 & HY \\
\hline 3 & Cannelin, Knut & Tutkimus Kemin kielenmurteesta & 1888 & HY \\
\hline 4 & Ojansuu, Heikki & $\begin{array}{l}\text { Suomen lounaismurteiden äänne- } \\
\text { historia. Vokaalioppi. Descendentti } \\
\text { esitys }\end{array}$ & 1901 & $\mathrm{HY}$ \\
\hline 5 & Airila, Martti & $\begin{array}{l}\text { Ä̈̈nnehistoriallinen tutkimus Tor- } \\
\text { nion murteesta. Murteen suhdetta } \\
\text { suomen muihin murteihin silmällä- } \\
\text { pitäen }\end{array}$ & 1912 & HY \\
\hline 6 & Laurosela, Jussi & $\begin{array}{l}\text { Ä̈̈nnehistoriallinen tutkimus Etelä- } \\
\text { Pohjanmaan murteesta. I. Konso- } \\
\text { nantit }\end{array}$ & 1913 & $\mathrm{HY}$ \\
\hline 7 & Rapola, Martti & $\begin{array}{l}\text { Kantasuomalaiset pääpainottomain } \\
\text { tavujen i-loppuiset diftongit suomen } \\
\text { murteissa }\end{array}$ & 1919 & HY \\
\hline 8 & Ikola, Niilo & $\begin{array}{l}\text { Ala-Satakunnan murteen ä̈̈nne- } \\
\text { historia I. Descendentti esitys } \\
\text { myöhäiskantasuomalaisten konso- } \\
\text { nanttien kehityksestä }\end{array}$ & 1925 & TY \\
\hline 9 & Lindén, Eeva & $\begin{array}{l}\text { Kaakkois-Hämeen murteiden } \\
\text { ä̈nnehistoria. I. Konsonantisto }\end{array}$ & 1942 & HY \\
\hline 10 & Ruoppila, Veikko & $\begin{array}{l}\text { Kotieläinten nimitykset Suomen } \\
\text { murteissa. I. Hevonen, nauta, lam- } \\
\text { mas, vuohi }\end{array}$ & 1943 & $\mathrm{HY}$ \\
\hline 11 & Virtaranta, Pertti & $\begin{array}{l}\text { Länsiyläsatakuntalaisten murteiden } \\
\text { ä̈nnehistoria. I. Konsonantit }\end{array}$ & 1946 & $\mathrm{HY}$ \\
\hline 12 & Ojajärvi, Aulis & $\begin{array}{l}\text { Sijojen merkitystehtävistä Itä- } \\
\text { Karjalan Maaselän murteissa. Nomi- } \\
\text { natiivi, genetiivi, akkusatiivi ja parti- } \\
\text { tiivi. Vertaileva funktio-opillinen } \\
\text { tutkimus }\end{array}$ & 1950 & $\mathrm{HY}$ \\
\hline 13 & Leskinen, Heikki & $\begin{array}{l}\text { Luoteis-Laatokan murteiden äänne- } \\
\text { historia. I. Konsonantit }\end{array}$ & 1963 & $\mathrm{HY}$ \\
\hline
\end{tabular}


AARIKKA Murteiden tutkimus väitöskirjojen viitteiden valossa

\begin{tabular}{|c|c|c|c|c|}
\hline 14 & Itkonen, Terho & $\begin{array}{l}\text { Proto-Finnic final consonants. Their } \\
\text { history in the Finnic languages with } \\
\text { particular reference to the Finnish } \\
\text { dialects. I:1. Introduction. The his- } \\
\text { tory of - } \mathrm{k} \text { in Finnish }\end{array}$ & 1965 & HY \\
\hline 15 & Pääkkönen, Matti & $\begin{array}{l}\text { Oulun seudun murteiden äänne- } \\
\text { historia. I. Sanansisäiset klusiilit } \\
\text { astevaihtelusuhteineen }\end{array}$ & 1971 & HY \\
\hline 16 & Räsänen, Seppo & Kainuun murteiden kaasussyntaksi & 1972 & HY \\
\hline 17 & Lehtimäki, Pekka & $\begin{array}{l}\text { Oi- ja ei-nominit Länsi-Uuden- } \\
\text { maan murteissa }\end{array}$ & 1972 & HY \\
\hline 18 & Räisänen, Alpo & $\begin{array}{l}\text { Kainuun murteiden ä̈̈nnehistoria. } \\
\text { I. Vokaalisto }\end{array}$ & 1972 & $\mathrm{HY}$ \\
\hline 19 & Rintala, Päivi & Suomen -läntä-loppuiset adjektiivit & 1972 & HY \\
\hline 20 & $\begin{array}{l}\text { Paunonen, } \\
\text { Heikki }\end{array}$ & $\begin{array}{l}\text { Monikon genetiivin muodostus suo- } \\
\text { men kielessä. I. Johdanto. Yksi- } \\
\text { vartaloisten kaksitavujen monikon } \\
\text { genetiivi suomen murteissa }\end{array}$ & 1974 & HY \\
\hline 21 & Mielikäinen, Aila & $\begin{array}{l}\text { Etelä-Savon murteiden äänne- } \\
\text { historia. I. Konsonantit }\end{array}$ & 1981 & JY \\
\hline 22 & Kuiri, Kaija & $\begin{array}{l}\text { Referointi Kainuun ja Pohjois- } \\
\text { Karjalan murteissa }\end{array}$ & 1984 & JoY \\
\hline 23 & $\begin{array}{l}\text { Nuolijärvi, } \\
\text { Pirkko }\end{array}$ & $\begin{array}{l}\text { Kolmannen sukupolven kieli. Hel- } \\
\text { sinkiin muuttaneiden suurten } \\
\text { ikäluokkien eteläpohjalaisten ja } \\
\text { pohjoissavolaisten kielellinen sopeu- } \\
\text { tuminen }\end{array}$ & 1986 & HY \\
\hline 24 & Länsimäki, Maija & $\begin{array}{l}\text { Suomen verbikantaiset in : ime } \\
\text {-johdokset }\end{array}$ & 1987 & $\mathrm{HY}$ \\
\hline 25 & Nahkola, Kari & $\begin{array}{l}\text { Yleisgeminaatio. Ä̈̈nteenmuutoksen } \\
\text { synty ja vaiheet kielisysteemissä } \\
\text { erityisesti Tampereen seudun } \\
\text { hämäläismurteiden kannalta }\end{array}$ & 1987 & $\mathrm{TaY}$ \\
\hline 26 & $\begin{array}{l}\text { Palander, } \\
\text { Marjatta }\end{array}$ & $\begin{array}{l}\text { Suomen itämurteiden erikois- } \\
\text { geminaatio }\end{array}$ & 1987 & $\mathrm{TaY}$ \\
\hline 27 & Grönholm, Maija & $\begin{array}{l}\text { Ruotsalaiset lainasanat Turun mur- } \\
\text { teessa }\end{array}$ & 1988 & ÅA \\
\hline 28 & Sivula, Jaakko & $\begin{array}{l}\text { Lintu soidessa sokea. Suomen mur- } \\
\text { teiden kiimatermistö }\end{array}$ & 1989 & HY \\
\hline 29 & Juusela, Kaisu & $\begin{array}{l}\text { Törmäysmurteen variaatiosta. Jälki- } \\
\text { tavun i-loppuisen diftongin edustus } \\
\text { Töysän murteessa }\end{array}$ & 1989 & $\mathrm{HY}$ \\
\hline 30 & Koivisto, Jouko & $\begin{array}{l}\text { Suomen murteiden refleksiivi- } \\
\text { taivutus }\end{array}$ & 1990 & JY \\
\hline 31 & Suihkonen, Paavo & $\begin{array}{l}\text { Klusiilien vaihtelusuhteet Kala- ja } \\
\text { Lestijokilaakson murteissa }\end{array}$ & 1992 & JY \\
\hline
\end{tabular}




\begin{tabular}{|c|c|c|c|c|}
\hline 32 & Laitinen, Lea & $\begin{array}{l}\text { Välttämättömyys ja persoona. Suo- } \\
\text { men murteiden nesessiivisten raken- } \\
\text { teiden semantiikkaa ja kielioppia }\end{array}$ & 1992 & $\mathrm{HY}$ \\
\hline 33 & Mantila, Harri & $\begin{array}{l}\text { Ei tääläkhän senthän jokhaishen } \\
\text { sanhan hootakhan panna. Jälki- } \\
\text { tavujen vokaalienvälisen h: } n \text { variaa- } \\
\text { tio peräpohjalaisissa murteissa }\end{array}$ & 1992 & OY \\
\hline 34 & Mäkelä, Matti & $\begin{array}{l}\text { Suomen murteiden kin ja kaan, } \\
\text { kään -liitteet. Morfologia ja leksikko }\end{array}$ & 1993 & JY \\
\hline 35 & Suihkonen, Pentti & $\begin{array}{l}\text { Frekventatiividerivaatio suomen } \\
\text { murteissa. Morfologis-fonologista } \\
\text { tarkastelua }\end{array}$ & 1994 & JY \\
\hline 36 & Palomäki, Ulla & $\begin{array}{l}\text { Dentaalisen affrikaatan perilliset } \\
\text { suomen murteissa. Kielikontakteihin } \\
\text { perustuva selitysmalli }\end{array}$ & 1998 & TY \\
\hline 37 & $\begin{array}{l}\text { Forsberg, } \\
\text { Hannele }\end{array}$ & $\begin{array}{l}\text { Suomen murteiden potentiaali. } \\
\text { Muoto ja merkitys }\end{array}$ & 1998 & JoY \\
\hline 38 & Krook, Kristiina & $\begin{array}{l}\text { Ensi tavun ie-, yö- ja uo-diftongien } \\
\text { avartuminen suomen murteissa }\end{array}$ & 1999 & TY \\
\hline 39 & Hurtta, Heikki & $\begin{array}{l}\text { Suomen murteiden askel-tyyppisten } \\
\text { nominien morfologiaa ja murre- } \\
\text { maantiedettä }\end{array}$ & 2000 & $\mathrm{TaY}$ \\
\hline 40 & Jarva, Vesa & $\begin{array}{l}\text { Venäläisperäisyys ja ekspressiivisyys } \\
\text { suomen murteiden sanastossa }\end{array}$ & 2003 & JY \\
\hline 41 & Kurki, Tommi & $\begin{array}{l}\text { Yksilön ja ryhmän kielen reaali- } \\
\text { aikainen muuttuminen. Kielen- } \\
\text { muutosten seuraamisesta ja niiden } \\
\text { tarkastelussa käytettävistä mene- } \\
\text { telmistä }\end{array}$ & 2005 & TY \\
\hline 42 & Kokko, Ossi & $\begin{array}{l}\text { Inkerinsuomen pirstaleisuus. Eräi- } \\
\text { den sijojen kehitys murteen yksilöl- } \\
\text { listymisen kuvastajana }\end{array}$ & 2007 & JoY \\
\hline 43 & Kunnas, Niina & $\begin{array}{l}\text { Miten muuttuu runokylien kieli. } \\
\text { Reaaliaikatutkimus jälkitavujen A- } \\
\text { loppuisten vokaalijonojen variaa- } \\
\text { tiosta vienalaismurteissa }\end{array}$ & 2007 & OY \\
\hline 44 & $\begin{array}{l}\text { Vaattovaara, } \\
\text { Johanna }\end{array}$ & $\begin{array}{l}\text { Meän tapa puhua. Tornionlaakso } \\
\text { pellolaisnuorten subjektiivisena } \\
\text { paikkana ja murrealueena }\end{array}$ & 2009 & $\mathrm{HY}$ \\
\hline 45 & Ylitalo, Riikka & $\begin{array}{l}\text { The realisation of prominence in } \\
\text { three varieties of standard spoken } \\
\text { Finnish }\end{array}$ & 2009 & OY \\
\hline 46 & Mustanoja, Liisa & $\begin{array}{l}\text { Idiolekti ja sen muuttuminen. } \\
\text { Reaaliaikatutkimus Tampereen } \\
\text { puhekielestä }\end{array}$ & 2011 & $\mathrm{TaY}$ \\
\hline 47 & $\begin{array}{l}\text { Nupponen, } \\
\text { Anne-Maria }\end{array}$ & $\begin{array}{l}\text { "Savon murre" savolaiskorvin. } \\
\text { Kansa murteen havainnoijana }\end{array}$ & 2011 & ISY \\
\hline
\end{tabular}


AARIKKA Murteiden tutkimus väitöskirjojen viitteiden valossa

\begin{tabular}{|c|c|c|c|c|}
\hline 48 & Väänänen, Milja & $\begin{array}{l}\text { Subjektin ilmaiseminen yksikön en- } \\
\text { simmäisessä persoonassa. Tutkimus } \\
\text { suomen vanhoista murteista }\end{array}$ & 2016 & TY \\
\hline 49 & Priiki, Katri & $\begin{array}{l}\text { Hän, se, tää vai toi? Vuorovaikutus- } \\
\text { sosiolingvistinen tutkimus henkilö- } \\
\text { viittauksista Kaakkois-Satakunnan } \\
\text { nykypuhekielessä }\end{array}$ & 2017 & TY \\
\hline
\end{tabular}

Kaikki aineistorajauksen 50 väitöskirjaa eivät täytä kaikkia rajauskriteerejä. Ensimmäisen rajauskriteerin mukaisesta joukosta (40 väitöskirjaa) jäi uupumaan useita väitöskirjoja, jotka käsittelevät murteita. Mekaanisen nimiperustaisen rajauskriteerin lisäksi täydensin aineistoa kymmenellä väitöskirjalla, joiden voi tulkita tutkivan ensisijaisesti murteita tai murteiden välisiä eroja (kriteeri 2) tai jotka perustuvat pääasiassa murreaineistoksi nimettyyn aineistoon (kriteeri 3). Erityisesti rajauskriteeri 3 sisällytti otokseen väitöskirjoja, jotka tutkivat esimerkiksi syntaksia tai morfologiaa, eivätkä niiden tekijät varmasti identifioi itseään murretutkijoiksi tai tutkimustaan murretutkimukseksi. Käytännössä kriteerien 2 ja 3 ero on näkökulma: käsitteleekö tutkimus ensisijaisesti alueellista vaihtelua tai jotain alueellista kielimuotoa ja sen kielenpiirteitä vai jotakin kielenpiirrettä ja sen ilmenemistä kieliaineistossa eli tässä tapauksessa murteissa? Yksinomaan nimistöä käsittelevät väitöskirjat olen rajannut aineistosta pois, sillä olen katsonut, että toisin kuin esimerkiksi syntaksin ja morfologian nimistöntutkimuksen keskeinen tutkimuskohde ei ole kielimuoto tai sen rakenteet eli murre systeeminä.

On myös todettava, ettei ole tarkkarajaista, mitä tarkoittaa, kun mainitaan väitöskirjan perustuvan "pääasiassa murreaineistoon". Tässä esittämieni väitöskirjojen lisäksi murreaineistoa ovat väitöstutkimuksissaan hyödyntäneet pelkästään 2000-luvulla ainakin Taru Salminen (2000), Jaakko Leino (2003), Pia Päiviö (2007), Heli Pekkarinen (2011) ja Emmi Hynönen (2016). Kaikkineen voi sanoa, että tekemäni rajaus on haastettavissa ja aineiston olisi voinut koostaa joiltakin osin toisin.

Viittaan tässä artikkelissa taulukon 1 väitöskirjoihin termillä murreväitöskirja. Niiden yksilöinnissä käytän niiden tekijöiden ja nimikkeiden sijaan tunnistenumeroita (o49) ja ilmestymisvuosia, jotka käyvät ilmi taulukosta 1. Olen päätynyt tähän ratkaisuun siksi, että tässä artikkelissa tarkastelen väitöskirjojen joukkoa kokonaisuutena - rajattuna mutta kattavana otoksena tutkimushistoriasta. Tarkoitukseni ei ole esittää arvottavia huomioita yksittäisten tutkijoiden yksittäisissä tutkimuksissa tekemistä valinnoista, vaikka joitakin yksittäisiin väitöskirjoihin liittyviä havaintoja aineistoa esitellessäni ja analysoidessani teenkin. Lista väitöskirjoista täydellisine julkaisutietoineen on lähdeluettelossa (ks. Aineslähteet).

Väitöskirjojen tunnistenumerot etenevät lineaarisesti suhteessa niiden ilmestymisvuosiin, mutta kaikkina vuosikymmeninä ei ole ilmestynyt yhtä monta väitöskirjaa. Eroja on myös yliopistojen välillä. Nämä tiedot on koottu taulukoihin 2 ja 3. Ennen vuotta 1870 suomen kielen alalla ${ }^{5}$ oli ilmestynyt neljä väitöskirjaa, mutta yksikään niistä ei käsittele rajaukseni mukaisesti murteita, joten ne puuttuvat taulukoista.

5. Oikeammin kyse on suomalais-ugrilaisen kielentutkimuksen ja suomen kielen alasta, sillä oppiaineet eriytyivät vuonna 1891 (Karlsson 1998: 8). 
Taulukko 2.

Suomen kielen alalla 1870-2017 ilmestyneiden murreväitöskirjojen määrä ( $N=50)$ ja väitöskirjojen kokonaismäärä $(\mathrm{N}=276)$ vuosikymmenittäin.

\begin{tabular}{l|cc} 
Julkaisuvuosi & Murreväitöskirjoja (N) & Väitöskirjoja yhteensä (N) \\
\hline $1870-1879$ & 2 & 3 \\
\hline $1880-1889$ & 2 & 4 \\
\hline $1890-1899$ & 0 & 2 \\
\hline $1900-1909$ & 1 & 2 \\
\hline $1910-1919$ & 3 & 4 \\
\hline $1920-1929$ & 1 & 2 \\
\hline $1930-1939$ & 0 & 2 \\
\hline $1940-1949$ & 3 & 6 \\
\hline $1950-1959$ & 1 & 3 \\
\hline $1960-1969$ & 2 & 7 \\
\hline $1970-1979$ & 6 & 19 \\
\hline $1980-1989$ & 9 & 25 \\
\hline $1990-1999$ & 9 & 45 \\
\hline $2000-2009$ & 7 & 77 \\
\hline $2010-2017^{6}$ & 4 & 66 \\
\hline Yhteensä & 50 & 267 \\
\hline
\end{tabular}

Taulukko 2 havainnollistaa, miten väitöstutkimusten määrä on kasvanut 1970-1980luvuilta alkaen. Kun 1900-luvun taitteessa ja alkuvuosikymmeninä fennistiikan alan väitöskirjoja ilmestyi muutamia, valmistui niitä 200o-luvun ensimmäisenä vuosikymmenenä lähemmäs 8o. Samaan aikaan rajaukseni mukaisten murreväitöskirjojen suhteellinen osuus on pienentynyt: 1900-luvun alussa murreväitöskirjat edustivat noin puolta ilmestyneiden väitöskirjojen määrästä, mutta 2000-luvulla murreväitöskirjojen osuus on vain noin kymmenesosa (11/143) kaikista fennistisistä väitöskirjoista. Osittain ero selittyy tieteenalan paradigmojen monimuotoistumisella ja laajentumisella, jota ovat käsitelleet myös väitöstutkimuksia systemaattisesti tarkastelleet Karlsson (1998) ja Leino (1992). Siinä, missä Pentti Leino (1992: 15) toteaa, että "murteiden asema on pysynyt vakaana" väitöskirjojen aineistojen ja aihepiirien kategoriana, voi oman tarkasteluni perusteella väittää jotakuinkin päinvastaista. Havaintojen ero johtunee siitä, että muutos on tapahtunut Leinon artikkelin ilmestymisen jälkeen: 1990-luvulla murreväitöskirjojen suhteellinen osuus oli vielä viidesosa kaikista fennistiikan väitöskirjoista. Huomattava kuitenkin on, että murreväitöskirjoja on ilmestynyt useita myös viime vuosikymmeninä, mikä osaltaan osoittaa, että murteentutkimuksella on vakiintunut asemansa tieteenalalla sen laajenemisesta ja monipuolistumisesta huolimatta.

6. Ilmestyneet väitöskirjat 31.5.2017 mennessä. 
Taulukko 3.

Suomen kielen alalla 1870-2017 ilmestyneiden murreväitöskirjojen ( $N=50)$, väitöskirjojen kokonaismäärän ( $N=276$ ) sekä murreväitöskirjojen suhteellisen osuuden jakautuminen yliopistoittain.

\begin{tabular}{|c|c|c|c|}
\hline Yliopisto & $\begin{array}{l}\text { Murreväitös- } \\
\text { kirjoja }(\mathrm{N})\end{array}$ & $\begin{array}{l}\text { Väitöskirjoja } \\
\text { yhteensä (N) }\end{array}$ & $\begin{array}{l}\text { Murreväitöskirjojen osuus } \\
\text { kaikista väitöskirjoista (\%) }\end{array}$ \\
\hline $\mathrm{HY}$ & 26 & 129 & 20 \\
\hline ISY7 & 4 & 10 & 40 \\
\hline JY & 6 & 36 & 17 \\
\hline OY & 3 & 30 & 10 \\
\hline $\mathrm{TaY}$ & 4 & 16 & 25 \\
\hline TY & 6 & 34 & 17 \\
\hline ÅA & 1 & 12 & 8 \\
\hline Yhteensä & 50 & 267 & 19 \\
\hline
\end{tabular}

Taulukossa 3 havainnollistettu väitöskirjojen jakautuminen yliopistoittain tuo selkeästi esiin, että suurin osa suomen murteita tarkastelevista väitöskirjoista on tehty Helsingin yliopistossa. Tähän vaikuttaa luonnollisesti se, että Helsingin yliopistossa oli pitkään ainoa suomen kielen oppiaine. Vuonna 1920 perustettiin Turun yliopisto ja sen suomen kielen oppiaine, ja vuonna 1934 perustetussa Jyväskylän Kasvatusopillisessa Korkeakoulussa oli suomen kielen professuuri. Muut suomen kielen oppituolit on perustettu vasta 1960-luvulla, ja väitöskirjoja alkoi ilmestyä muualta kuin Helsingistä ja Turusta vasta vuonna 1967 (P. Leino 1992: 13). Murreväitöskirjojen suhteellisten osuuksien tarkasteleminen kertoo tästä syystä enemmän kuin yksin väitöskirjojen määrät. Suhteellisesti eniten (40 \%) murteita käsitteleviä väitöskirjoja on ilmestynyt ItäSuomen yliopistosta ja vähiten Vaasan yliopistosta, josta valmistuneista väitöskirjoista yksikään ei käsittele suomen murteita ja jota ei siksi ole listattu taulukkoon 3.

\section{Lähdeluettelot aineistona}

Tämän artikkelin aineistona on väitöskirjojen kirjallisuuslähteistä koostettu lähdetietokanta, joka perustuu murreväitöskirjojen 7-47 (ks. taulukkoa 1) lähdeluetteloihin. ${ }^{8}$ Koostin 41 lähdeluettelosta yhden datakokonaisuuden, jossa on yhteensä 9530 lähderiviä. Yhdellä tietokannan lähderivillä on tiedot lähteen tekijästä, julkaisuvuodesta, nimikkeestä ja julkaisutiedoista (esim. kustantaja ja painos). Nämä tiedot on saatu suoraan lähdeluetteloista. Lisäksi olen lisännyt manuaalisesti tiedon lähteen tekijän suku-

7. Itä-Suomen yliopisto oli ennen vuotta 2010 Joensuun yliopisto (JoY).

8. Ensimmäisessä seitsemässä (0-6) väitöskirjassa ei ole nykymuotoista digitoitavissa olevaa lähdeluetteloa, ja kaksi viimeksi ilmestynyttä (48 ja 49) eivät aineiston käsittelyllisistä syistä ehtineet tämän artikkelin analyysiin. 
puolesta ja kotimaisuudesta (vs. ei-kotimaisuudesta). Tässä artikkelissa esitetyt analyysit ja kuvaajat on tuotettu Excel- ja SPSS-ohjelmistoilla lähdetietokannasta. Julkaisen tietokannan avoimena datana tämän artikkelin julkaisemisen yhteydessä FINCLARIN-konsortion Kielipankissa. ${ }^{9}$

Niin kuin missä tahansa ihmisen tuottamassa tiedossa myös väitöskirjojen lähdeluetteloissa on epäjohdonmukaisuuksia ja suoranaisia virheitä, kuten erilaisia tapoja kirjata teosnimikkeet ja vääriä teosten ilmestymisvuosia. Tätä variaatiota olen yhdenmukaistanut aineiston käsittelyn yhteydessä paitsi manuaalisesti ${ }^{10}$ myös OpenRefineohjelmistoa hyödyntäen.

On huomattava, etteivät lähdeluettelot kerro mitään viittauksien laadusta, sillä tarkastelu on puhtaan kvantitatiivista (ks. bibliometrisen tarkastelun ongelmista esim. Karlsson 1994: 5). Lähteet eivät siis sisällä tietoa siitä, missä kontekstissa ja miksi tutkimuskirjallisuuteen on viitattu: teoreettisen viitekehyksen, metodologian, hypoteesin, johtopäätösten, samanmielisyyden vai erimielisyyden funktiossa. Lisäksi lähteet ovat lähdeluetteloissa ja siten lähdetietokannassa toistensa kanssa samanarvoisia, vaikka johonkin teokseen tai tekijään on saatettu viitata yksittäisessä väitöskirjassa useaan otteeseen tai vain kerran. Tästä laadullisesta heikkoudesta huolimatta lähdeluettelot toimivat väitöskirjojen kuten minkä tahansa tutkimuskirjallisuuden selkärankana ja osoittavat, mille tieteelliselle tai muulle aiemmin julkaistulle kirjallisuudelle tutkimus rakentuu. Kvantitatiivinen lähteiden tarkasteleminen siis kertoo joitakin oleellisia asioita tutkimushistoriasta mutta ei kaikkea eikä täydellisesti.

Väitöskirjojen lähdeluetteloiden digitointiprosessi" ${ }^{11}$ oli aikamatka suomalaisen tieteenhistorian viittauskäytäntöjen kehittymiseen. Kuten edellä alaviitteessä jo huomautin, ensimmäisessä seitsemässä murteita käsittelevässä väitöskirjassa ei ole lähdeluetteloa, vaan viittaukset on merkitty pääasiassa alaviittein, jos ollenkaan. Ensimmäinen nykykäytänteiden mukainen lähdeluettelo on väitöskirjassa 7 (1919) otsikkoinaan "B. Vanha kirjallisuus" ja "C. Muita". Ensimmäinen varsinaisesti lähdeluetteloksi nimetty lähdelista on vasta väitöskirjassa 9 (1942) otsikolla "Kirjallisuus- ja lähdeluetteloa".

Suomalaisten niin sanottujen kansallisten tieteiden pienuudesta niiden ensitaipaleilla kertoo esimerkiksi se, että käytössä on ollut pitkään teoslyhenteet (esim. "Kettunen VÄH = Lauri Kettunen. Vatjan kielen äännehistoria"). Erityisesti äännehistorioiden osalta lyhennekäytäntö on pitänyt pintansa pitkälle ja lyhenteet ovat olleet hyvin vakiintuneita. Vasta väitöskirjassa 22 (1984) lyhenteistä on luovuttu myös äännehistorioiden kohdalla ja kaikkeen tutkimuskirjallisuuteen viitataan tekijän nimellä, teosnimikkeellä ja julkaisun ilmestymisvuodella.

9. Aarikka, Lotta 2018: Murteita käsittelevien fennististen väitöskirjojen lähdetietokanta. Kielipankki. http://urn.fi/urn:nbn:fi:lb-2018092801. Aineiston lyhenne: fedidi.

10. Olen yhdenmukaistanut käsityönä tekijänimiä (esim. Arvi Jännes $\rightarrow$ Arvid Genetz) ja nimikkeiden julkaisuvuosia. Yhdenmukaistaminen ei kuitenkaan ole täydellistä. Olen pääasiassa pyrkinyt käyttämään nimikkeen alkuperäistä ilmestymisvuotta - kuitenkin niin, että painostiedot säilyvät julkaisutiedoissa. Jos kirjasarjaan on viitattu kokonaisuutena, olen yleensä jakanut nimikkeet erillisiksi lähderiveikseen.

11. Digitointi sisälsi seuraavat työvaiheet: lähdeluetteloiden skannaus, tekstintunnistus ABBYY FineReader 12 -ohjelmistolla, tekstitiedostojen muokkaaminen csv-tiedostoiksi manuaalisesti, csv-tiedostojen muokkaaminen xls-tiedostoksi, 41 xls-tiedoston yhdistäminen yhdeksi tiedostoksi, datan yhdenmukaistaminen OpenRefine-ohjelmistolla sekä manuaalinen tarkistaminen. 
Myös artikkeleiden lähdemerkinnöissä on hajontaa. Ensimmäisissä väitöskirjoissa artikkeleita ei ole merkitty tarkasti lähdeluetteloihin, vaan viittaukset saattavat olla hyvinkin summittaisia. Esimerkiksi väitöskirjassa 11 (1946) viitataan artikkeleihin seuraavasti: "merkinnät Tunkelo Vir, 1925, Jaakkola Satakunta V, Rytkönen Kalevalaseuran vuosikirja 17 jne. tarkoittavat näiden kirjoittajien mainituissa julkaisuissa olevia tutkielmia”. Väitöskirja 12 (1950) muodostaa viittauskäytännöiltään monella tapaa murroskohdan: viittaukset monografioihin tai "tyypillisiin lähteisiin" on tehty lyhenteillä, mutta väitöskirjassa on listaus "muista lähteistä", kuten artikkeleista, joihin on viitattu nykykäytänteiden mukaisesti (sukunimi, etunimi, vuosiluku, nimike).

Eniten lähteitä ( $574 \mathrm{kpl})$ on väitöskirjassa 43 (2007), vähiten $(24 \mathrm{kpl})$ väitöskirjassa 8 (1925). Taulukossa 4 on esitetty, miten monta lähdettä sadan lähteen tarkkuudella väitöskirjoissa on. Suurimmassa osassa väitöskirjoja (25 kpl) lähteitä on 100-299.

\section{Taulukko 4.}

Lähteiden määrät väitöskirjoissa.

\begin{tabular}{l|c}
$\begin{array}{l}\text { Lähdettä/ } \\
\text { lähdeluettelo }\end{array}$ & Väitöskirjoja (N) \\
\hline$<100$ & 5 \\
$100-199$ & 12 \\
$200-299$ & 13 \\
$300-399$ & 6 \\
$400-499$ & 4 \\
$500-$ & 1 \\
\hline
\end{tabular}

Lähteiden määrä vaihtelee väitöskirjoissa erittäin paljon, mutta voi sanoa, että lähdemäärä keskimääräisesti kasvaa sitä mukaa, mitä uudempi väitöskirja on. Lähteiden määrän vaihtelua voi tarkastella kuviosta 1.

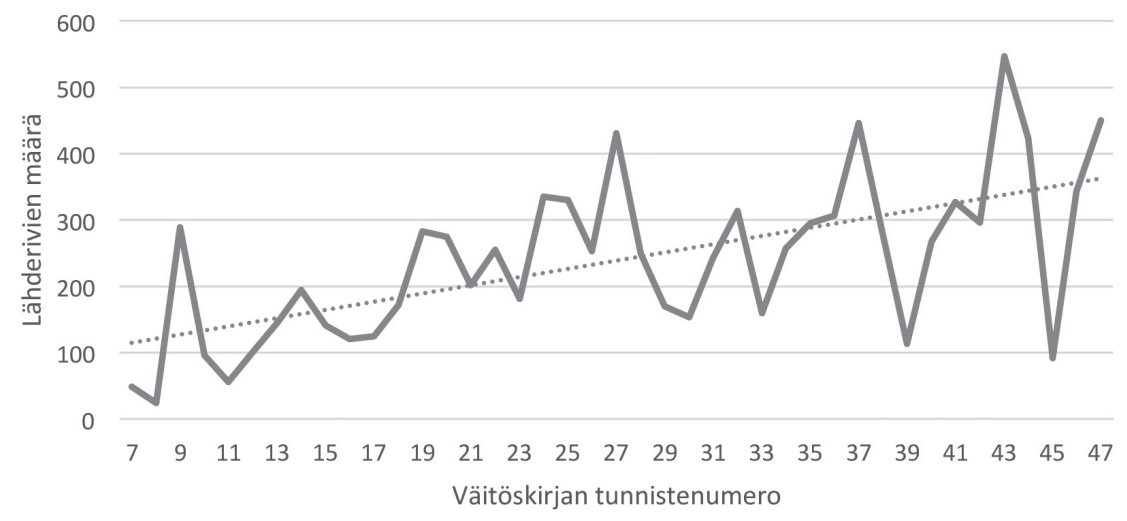

Kuvio 1.

Lähderivien määrä väitöskirjoittain ( $N=9783)$. 


\section{Lähdetietokanta: tekijät, nimikkeet ja julkaisuvuodet}

Kuten luvussa 5 kuvailin, tämän artikkelin aineisto koostuu 41 väitöskirjan (väitöskirjat 7-47, taulukko 1) lähdeluetteloista, jotka muodostavat yhteensä 9783 lähderivin tietokannan. Lähdetietokannan riveiltä löytyy tiedot 2657 eri tekijästä ja 5520 eri nimikkeestä.

Lähdetietokannan tekijätietoja analysoin alaluvussa 6.1. Tarkastelen ensiksi, ketkä ovat viitatuimmat tekijät, ja toisekseen, mikä on tekijöiden sukupuoli ja kansallisuus (kotimainen/ei-kotimainen) sekä millaista ajallista variaatiota näissä muuttujissa ilmenee. Alaluvussa 6.2 analysoin lähdetietokannan nimiketietoja ja esitän, mitkä ovat suomalaisen murteentutkimuksen viitatuimmat teokset. Lopulta alaluvussa 6.3 käyn lävitse lähdetietokannan nimikkeiden julkaisuvuosia.

\subsection{Tekijät}

Tässä alaluvussa tarkastelen lähdetietokannan tekijätietoja. Lähdetietokannan 9783 rivillä viitataan yhteensä 2657 tekijään. Lainkaan tekijätietoa ei ole 429 rivillä 9783 :sta. Tämä johtuu monesta syystä: Osa tekijättömistä riveistä on teoksia, joilla ei ole varsinaista tekijää vaan toimittaja tai toimittajia. Osasta väitöskirjojen lähdeluettelorivejä puuttuu tyystin tekijä, ja lähdetiedot on ilmoitettu vain nimikkeen ja vuosiluvun avulla. Mitä tulee viittausten frekvenssiin, 2657 tekijästä vain 150 on sellaista, joihin viitataan tietokannassa kymmenen kertaa tai useammin. Lähdetietokannan tekijätietoja kuvailevat luvut on koottu taulukkoon 5.

\section{Taulukko 5.}

Koonti lähdetietokannan tekijätiedoista.

\begin{tabular}{lr} 
Lähdetietokannan tekijätiedot & \\
\hline Lähderivejä & 9783 \\
Tekijättömiä lähderivejä & 429 \\
Tekijöitä & 2657 \\
Tekijöitä, joihin viitattu & \\
$\geq 10$ kertaa & 150 \\
\hline
\end{tabular}

Mainittava on, etten lähdetietokantaa koostaessani ole eritellyt kahdeksi riviksi tekijätietoja, joissa on useampi tekijä (esim. Aaltonen, Olli \& Wiik, Kalevi), vaan olen jättänyt nimien yhdistelmän omaksi tekijäkseen yhdelle lähderiville.

Tekijöiden frekvenssi on lähdetietokannassa selvästi painottunut. Toisin sanoen pieneen joukkoon kirjoittajia viitataan useasti, kun taas isoon joukkoon viitataan vain kerran. Tätä havainnollistaa kuvio 2. 


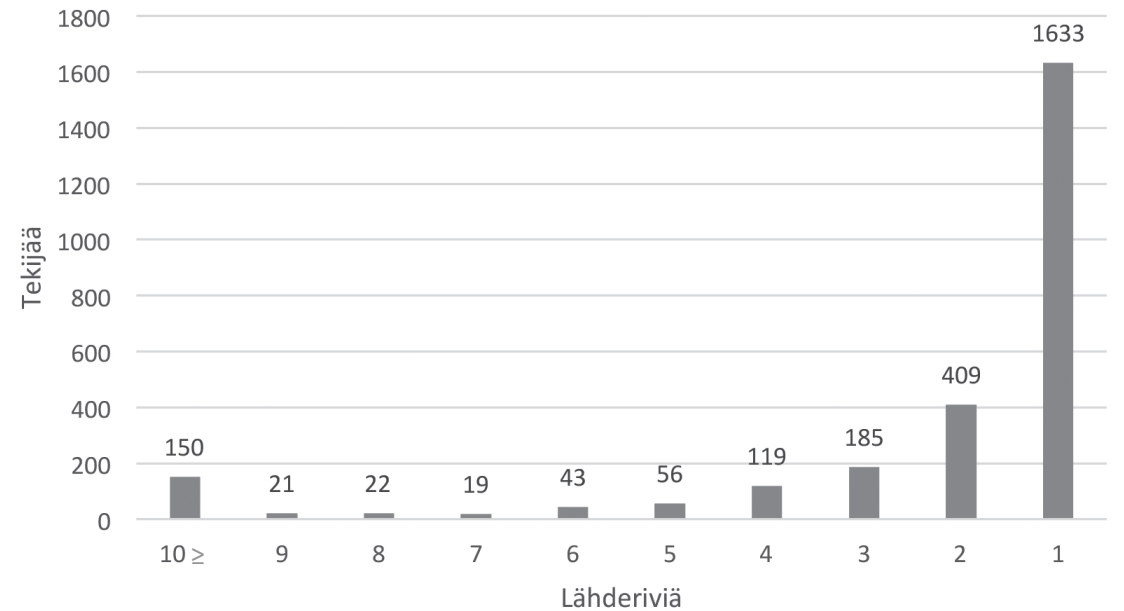

Kuvio 2.

Tekijöiden lähderivimäärä lähdetietokannassa ( $\mathrm{N}=2$ 657).

Kuviossa 3 on eritelty tarkemmin tekijöiden viitatuin ääripää eli ne tekijät, joilla on lähdetietokanta-aineistossa kymmenen riviä tai enemmän. Kuten kuviosta 2 käy ilmi, tällaisia tekijöitä on vain 150. Eniten lähdetietokannan lähderivejä on Lauri Kettusella (316 kpl), kun taas 17 tekijällä on kullakin kymmenen riviä lähdetietokannassa.

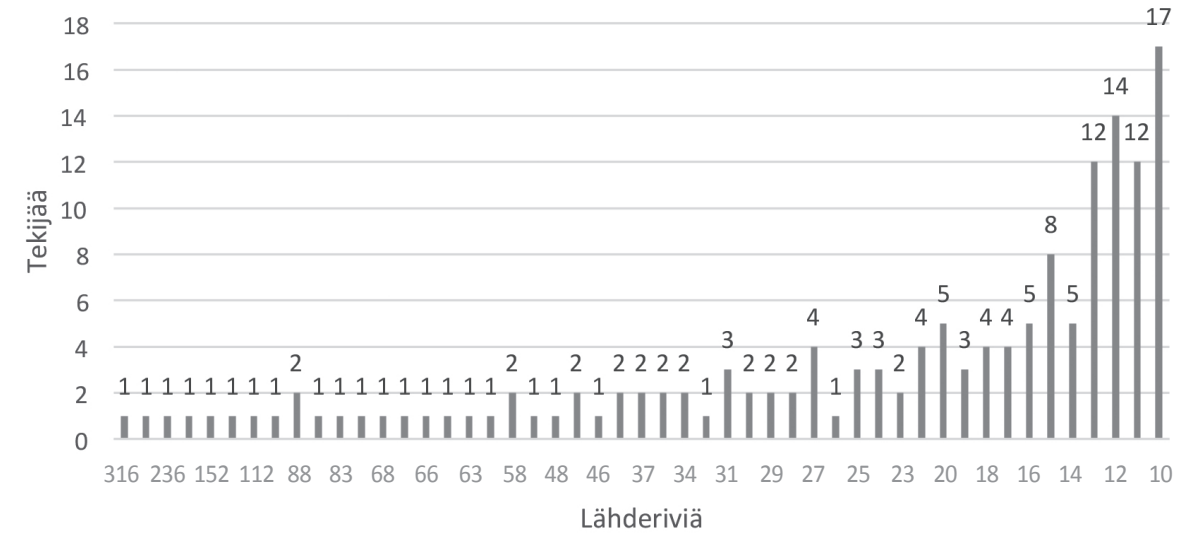

Kuvio 3.

Niiden tekijöiden määrä, joilla on lähdetietokannassa kymmenen riviä tai enemmän $(\mathrm{N}=150)$. 
Tekijäfrekvenssiin pohjautuvaan tarkasteluuni liittyy myös ongelmia. ${ }^{12}$ Ensinnäkin koska frekvenssiä ei ole suhteutettu väitöskirjojen ilmestymisvuosiin, se suosii vanhempia tutkijoita. Toisin sanoen Kettunen, jonka tutkijanura on alkanut 1900-luvun alussa, on voinut tulla viitatuksi kaikissa lähdetietokannan 41 väitöskirjassa. Sen sijaan tutkijat, joiden aktiiviura sijoittuu myöhempiin vuosikymmeniin, ovat voineet tulla viitatuiksi pienemmässä määrässä väitöskirjoja aktiiviuransa alun ajankohdasta riippuen. Tekijätarkastelussa on myös hyvä pitää mielessä, etten analyysissani ole ottanut huomioon, kuinka monessa väitöskirjassa kuhunkin tekijään viitataan. Joku yksittäinen tekijä saattaa siis painottua, vaikka häneen viitattaisiin vain yhdessä väitöskirjassa, mutta siinä on viitteitä moneen hänen tekemäänsä teokseen.

Näistä mainituista analyysini heikkouksista huolimatta aineistosta on mahdollista tarkastella viitatuimpien tekijöiden kärkijoukkoa. Taulukossa 6 on listattuna lähdetietokannan viitatuimmat 27 tekijää, jotka muodostavat prosentin koko tietokannan uniikeista tekijöistä. Yhteensä näillä tekijöillä on 2672 lähderiviä, mikä on 27 \% tietokannan riveistä, joilla on tekijätieto. On perusteltua väittää, että nämä tekijät ovat erityisen keskeisessä asemassa suomalaisen murteentutkimuksen tutkimushistoriassa.

Taulukko 6.

Viitatuin sadasosa eli 27 eniten lähteenä käytettyä tekijää lähdetietokannassa sekä vertailu Virittäjän 1/1981-1/1993 lähdeluetteloista koottuun aineistoon (Karlsson 1994).

\begin{tabular}{l|c|c} 
Tekijä & $\begin{array}{l}\text { Lähderivimäärä } \\
\text { murreväitöskirja- } \\
\text { lähdetietokannassa }\end{array}$ & $\begin{array}{l}\text { Lähderivimäärä Virittäjiin } \\
\text { 1/1981-1/1993 perustuvassa } \\
\text { lähdeluetteloaineistossa }\end{array}$ \\
\hline Kettunen, Lauri & 316 & 77 \\
\hline Itkonen, Terho & 241 & 117 \\
\hline Rapola, Martti & 236 & 80 \\
\hline Ojansuu, Heikki & 187 & 31 \\
\hline Virtaranta, Pertti & 152 & 60 \\
\hline Paunonen, Heikki & 127 & 21 \\
\hline Mielikäinen, Aila & 112 & - \\
\hline Setälä, E. N. & 92 & 73 \\
\hline Hakulinen, Lauri & 88 & 92 \\
\hline Räisänen, Alpo & 88 & 32 \\
\hline Leskinen, Heikki & 87 & - \\
\hline
\end{tabular}

12. Haluan tässä kohden tuoda esiin Virittäjän anonyymin arvioijan erinomaisen ehdotuksen tekijäkohtaisesta impaktilaskelmasta, jossa jaettaisiin sitaatioiden määrät tutkijoiden aktiivisten vuosien määrällä. Tällainen kattava ja luotettava analyysi edellyttäisi, että lähdetietokantadataan täydennettäisiin manuaalisesti tutkijoiden uran aloitus- ja lopetusvuositiedot kaikkien siinä esiintyvien tutkijoiden ( $N=2657)$ tai vähintään kahdella lähderivillä esiintyvien tutkijoiden ( $N=1024)$ osalta - muuten ongelma pidempään aktiivisten tutkijoiden painottumisesta ei korjaannu. Vaikka lähestymistapa olisi hyvä ja tuottaisi erilaisia tuloksia kuin käyttämäni esittämistapa, se on tätä artikkelia ajatellen työläs. Olen pyrkinyt tuomaan esille oman analyysitapani heikkoudet mahdollisimman rehellisesti ja kattavasti. Katson, että valitsemani frekvenssiin pohjautuva analyysitapa tuottaa heikkouksista huolimatta relevanttia ja hyödyllistä tietoa lähdetietokanta-aineiston tekijätiedoista. 
AARIKKA Murteiden tutkimus väitöskirjojen viitteiden valossa

\begin{tabular}{lcc}
\hline Ruoppila, Veikko & 81 & 30 \\
\hline Itkonen, Erkki & 78 & 93 \\
\hline Labov, William & 68 & - \\
\hline Tunkelo, E. A. & 67 & - \\
\hline Wiik, Kalevi & 66 & 21 \\
\hline Nirvi, R. E. & 65 & - \\
\hline Posti, Lauri & 63 & 50 \\
\hline Palander, Marjatta & 61 & - \\
\hline Genetz, Arvid & 58 & - \\
\hline Laurosela, Jussi & 58 & - \\
\hline Turunen, Aimo & 55 & - \\
\hline Ikola, Niilo & 48 & - \\
\hline Lindén, Eeva & 47 & - \\
\hline Karlsson, Fred & 46 & - \\
\hline Ravila, Paavo & 45 &
\end{tabular}

Eniten lähteenä käytetyn 27 tutkijan joukkoa on kiinnostavaa verrata Karlssonin Virittäjässä 1/1981-1/1993 julkaistujen artikkelien lähteiden analyysiin (Karlsson 1994: 12-13). Vaikka Karlssonin aineistoa ei ole rajattu temaattisesti vaan analyysi on tehty kaikkien Virittäjässä ilmestyneiden artikkelien lähdeluetteloiden pohjalta, vertailu osoittaa, että eniten lähteinä käytettyjen tekijöiden joukko on osin samankaltainen. Karlssonin aineistossa ( 5 030 lähderiviä) eniten lähteinä käytettyjen tekijöiden (> 20 lähdeluetteloriviä) joukko koostuu 23 tekijästä, joista 14 löytyy oman tarkasteluni eniten lähteenä käytettyjen tekijöiden joukosta. ${ }^{13}$ Lähderivien määrän mukainen järjestys poikkeaa Karlssonin vastaavasta, mutta kärkilistojen päällekkäisyys osoittaa sen, minkä Karlsson (1994: 13) itsekin toteaa: diakronisesti painottunut fonologinen ja morfologinen tutkimus sekä dialektologia ovat keskeinen osa fennististä traditiota.

Kuten luvussa 4 mainitsin, lisäsin lähdetietokantaan lähdeluetteloista pääsääntöisesti löytyvän tiedon (tekijä, nimike, julkaisuvuosi, julkaisutiedot) lisäksi myös metadataa tekijästä. Ensiksi lisäsin tekijöistä kansallisuustiedon käyttäen karkeaa jaottelua kotimaisiin ja ei-kotimaisiin. Toiseksi merkitsin tiedon tekijän sukupuolesta. Molemmat lisäykset perustuvat subjektiiviseen tekijän nimeen perustuvaan arviooni ja pääasiassa internethaulla varmistettuun tietoon. Tekijän sukupuolen päättelin binääristä sukupuolta indikoivasta etunimestä ja kotimaisuuden pääasiassa siitä, onko tekijän nimi suomen- tai ruotsinkielinen. Koska tekijöitä on paljon (2 645), en merkinnyt

13. Karlssonin eniten lähteinä käytetyt tekijät, jotka puuttuvat tämän tarkastelun eniten lähteinä käytettyjen tekijöiden joukosta, ovat seuraavat (Karlssonin Virittäjässä 1/1981-1/1993 julkaistujen artikkelien lähteiden analyysin N / murreväitöskirjalähdetietokannan N): Auli Hakulinen (92/28), Jorma Koivulehto (66/30), Osmo Ikola (52/34), Aarni Penttilä (33/37), Mikko Korhonen (31/16), Jalo Kalima (25/24), Antti Sovijärvi (24/22), Pauli Saukkonen (22/37) ja Paavo Siro (22/17). 
tietoja itselleni epäselviin tapauksiin sellaisten tekijöiden kohdalle, joihin on viitattu vain kerran.

Kuvio 4a havainnollistaa, että lähderiveittäin tarkasteltuna miestekijä on edustettuna 6774 tapauksessa. Toisin sanoen lähderiveistä noin kahdessa kolmasosassa (69\%) on teos, jonka tekijä on mies. Kun tarkastellaan sukupuolten edustusta tekijöittäin kuviossa 4b, miesten edustus vähenee noin puoleen (55\%): yhteensä 2657 tekijästä 1453 on miehiä. Koko lähdetietokantaa tarkastellessa havaitaan, että miehiin siis paitsi viitataan useammin heitä on myös enemmistö tekijöistä, joihin viitataan. Havaintoa olisi houkuttelevaa selittää sillä, että naiset ovat astuneet tieteen maailmaan myöhemmin kuin miehet. Kuitenkin lähdetietokannan aineslähteenä käytetyistä väitöskirjoista 20 eli lähes täsmälleen puolet on naistutkijan tekemiä ja keskimääräinen lähteiden määrä kasvaa sen mukaan, mitä uudempi väitöskirja on. Suurin osa tietokantadatan lähteistä on julkaistu vuoden 1950 jälkeen (ks. kuviota 10 s. 413). Ero miesten ja naisten edustuksessa ei siis selity yksin sillä, ettei naistutkijoita ole tieteenalan alkuvaiheissa ollut, vaikka tällä tosiasialla lienee vaikutusta. Myös se, että taulukossa 6 esitelty viitatuimpien tekijöiden joukko koostuu lähes yksinomaan miehistä (24/27), vaikuttanee lähderiveittäin tehdyn tarkastelun (kuvio 4a) miesvaltaisuuteen. Sukupuolten edustuksen erojen kvalitatiivinen jatkoanalyysi olisi kiinnostavaa muttei tässä artikkelissa laajuutensa vuoksi mahdollista.

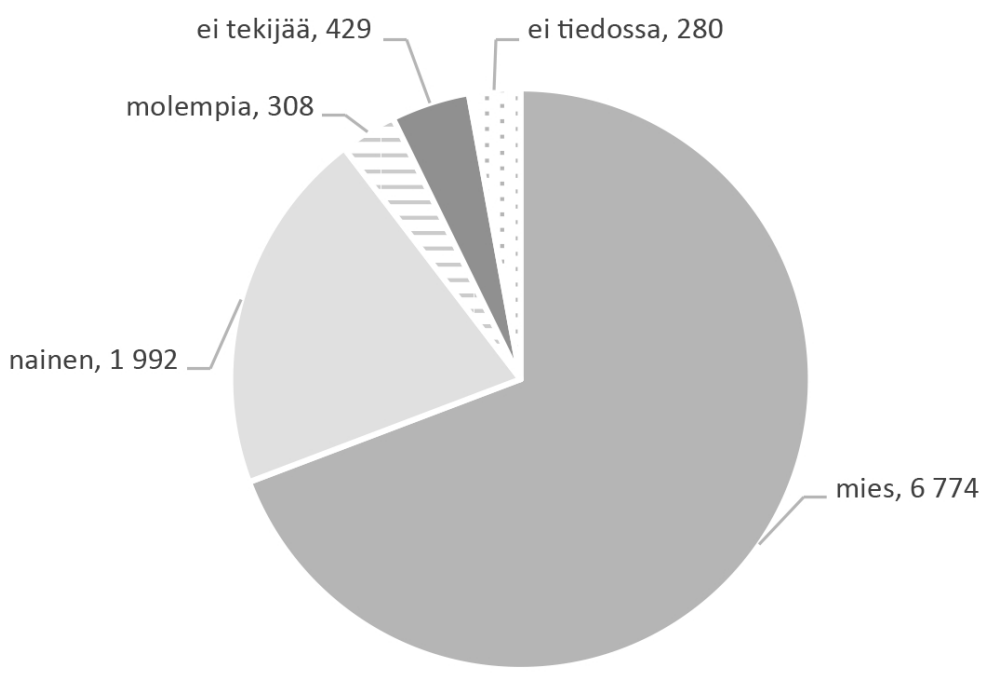

Kuvio 4a.

Tekijöiden sukupuoli lähderiveittäin tarkasteltuna $(\mathrm{N}=9783) .{ }^{14}$

14. Kategoria "ei tiedossa" tarkoittaa lähteitä, joiden tekijää ei tiedetä, ja kategoria "molempia" viittaa lähteeseen, jonka tekijöinä on sekä miehiä että naisia. 


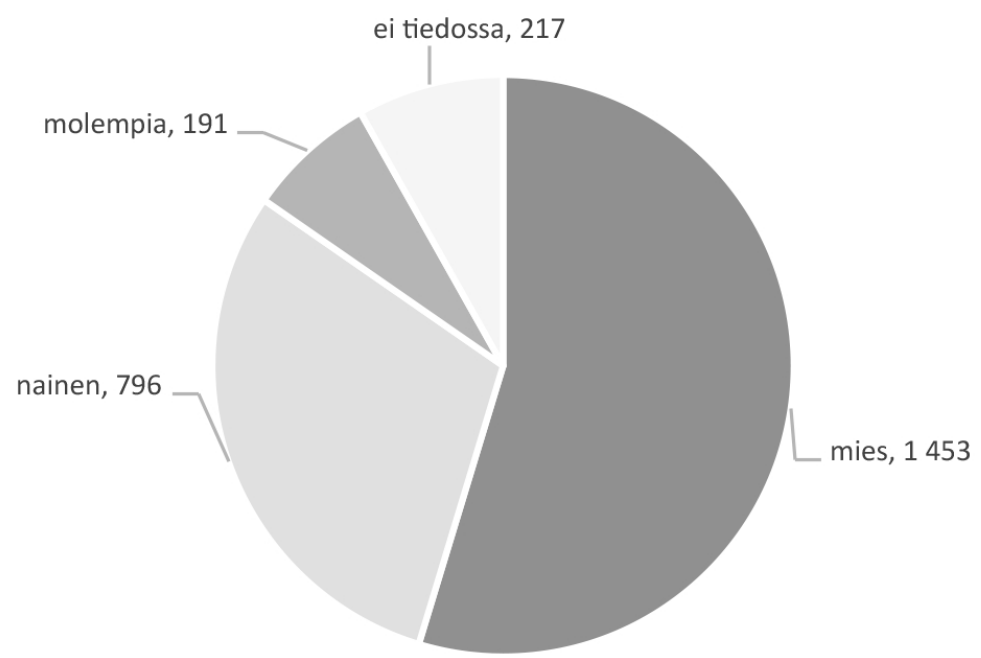

Kuvio $4 b$.

Tekijöiden sukupuoli tekijöittäin tarkasteltuna ( $\mathrm{N}=2657) .{ }^{15}$

Lähdetietokannasta on mahdollista tarkastella myös sukupuolten edustuksen kehitystä. Kuvio 5 esittää ristiintaulukoinnin perusteella laaditun käyrän naispuolisten tekijöiden prosentuaalisen osuuden kehityksestä.

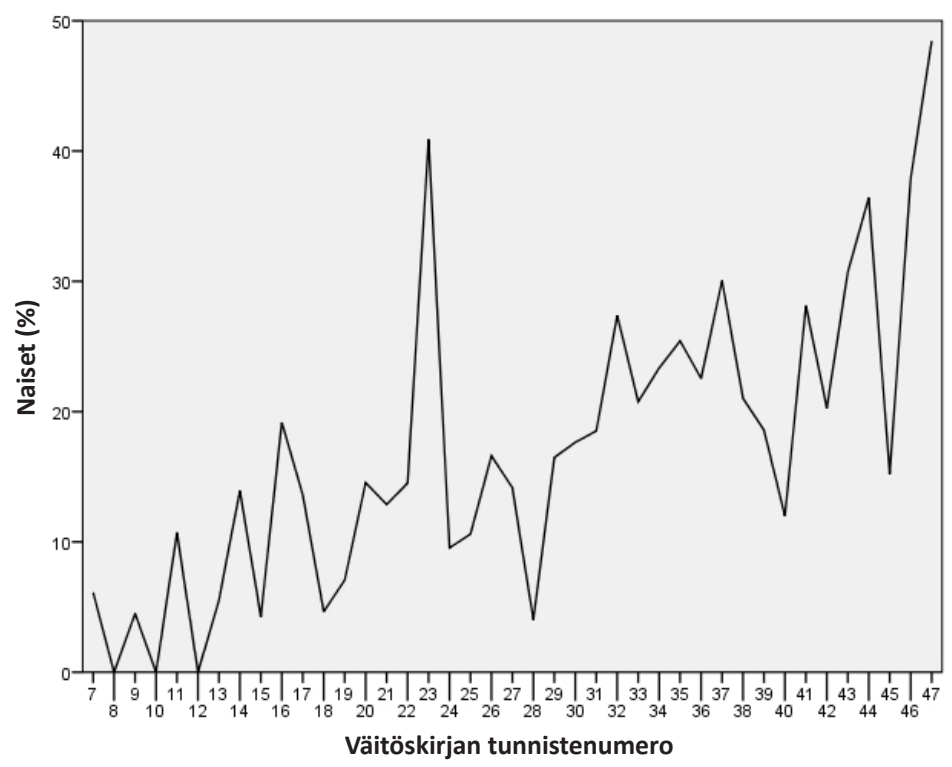

Kuvio 5.

Naispuolisten tekijöiden prosentuaalisen edustuksen kehitys.

15. Kategoria "ei tiedossa" tarkoittaa tekijää, jonka sukupuolta ei ole merkitty aineistoon, "molempia" puolestaan viittaa usean tekijän yhdistelmään, jossa on sekä mies- että naistekijöitä. 
Kuviosta 5 on helppo havaita, että väitöskirjojen välillä on runsaasti variaatiota naistekijöiden edustuksessa - nollasta prosentista (väitöskirjat 8 [1925], 10 [1943] ja 12 [1950]) lähes 50 prosenttiin (väitöskirja 47 [2011]). Väitöskirjan 28 (1989) jälkeen naistekijöiden edustus lähteissä ei ole laskenut alle kymmeneen prosenttiin.

Kuvio 6a havainnollistaa, että lähderiveittäin tarkasteltuna kotimaisten tekijöiden edustus on 7 062. Toisin sanoen lähdeviitteistä lähes kolmessa neljäsosassa $(72 \%)$ on kyse teoksesta, jonka tekijä on kotimainen.

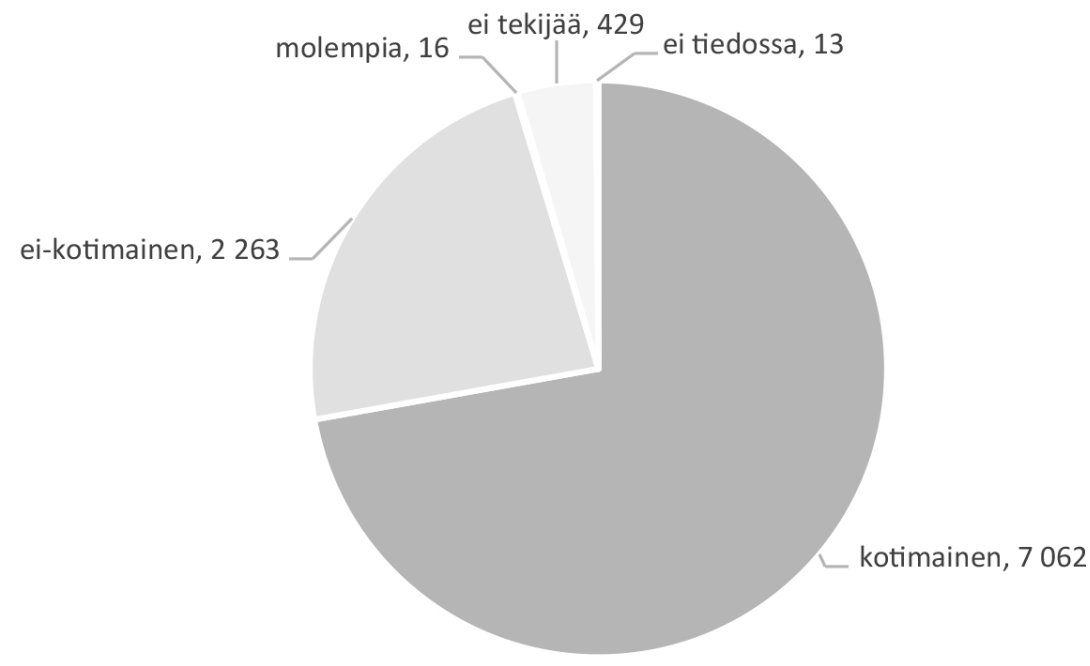

Kuvio $6 a$.

Tekijöiden kotimaisuus lähderiveittäin tarkasteltuna. ${ }^{16}$

Kun tarkastellaan kotimaisuuden edustusta tekijöittäin kuviossa 6b, osuus vähenee noin puoleen ( $55 \%$ ): yhteensä 2657 tekijästä 1458 on kotimaisia. Kotimaisiin tutkijoihin siis paitsi viitataan useammin heitä myös on tekijöissä noin 300 enemmän kuin eikotimaisia tekijöitä. Tulos on odotettu: myös Karlssonin bibliometrisissä analyyseissa on havaittavissa aiemminkin tavattu niin kutsuttu kansallinen vinouma (nationalistic bias). Toisin sanoen tutkijat viittaavat useammin oman maansa tutkijoihin kuin ulkomaisiin tutkijoihin (Karlsson 1994: 9). Osittain tulosta selittänee fennistiikan ja erityisesti murteentutkimuksen kansallinen luonne.

16. Kategoria "ei tiedossa" tarkoittaa lähteitä, joiden tekijää ei tiedetä, "molempia" lähdettä, jonka tekijänä on sekä kotimaisia että ei-kotimaisia tutkijoita. 


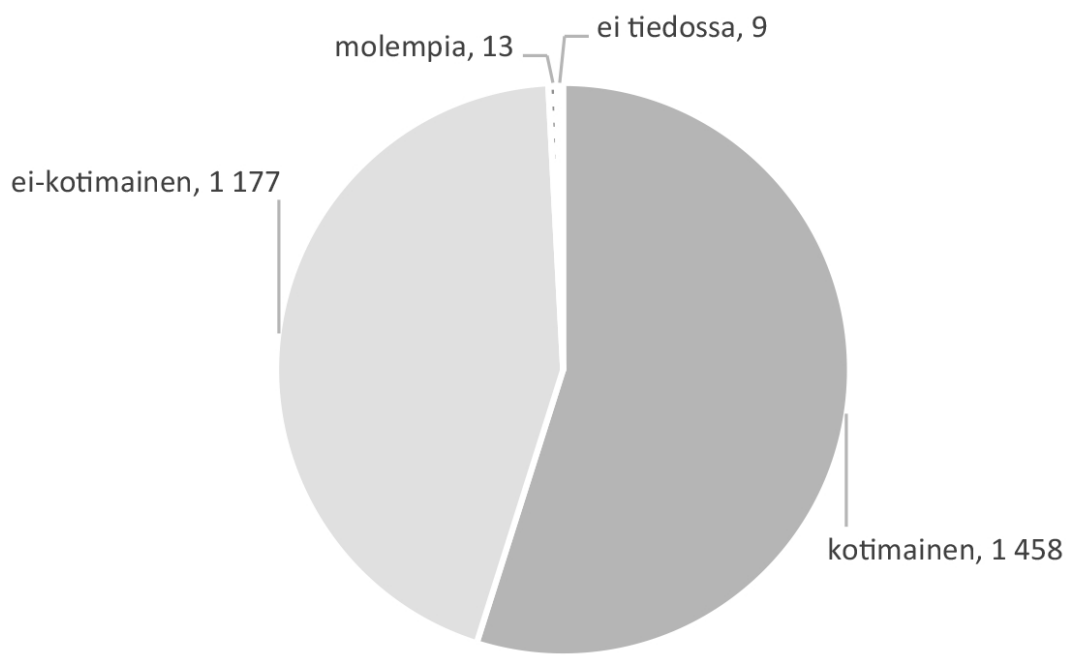

Kuvio $6 b$.

Tekijöiden kotimaisuus tekijöittäin tarkasteltuna. ${ }^{17}$

Erityisesti kansallisuutta tarkasteltaessa on huomion arvoista, että lähdetietokantadatassa on hämmästyttävän vähän lähderivejä (16 kpl), joiden tekijänä olisi kotimainen ja ei-kotimainen tekijä yhdessä. Sama näkyy myös tekijätarkastelussa: vain 13 tekijätietoa koostuu kotimaisen ja ei-kotimaisen tutkijan yhdistelmästä. Murreväitöskirjoissa ei siis viitata juuri lainkaan tutkimukseen, joka olisi kotimaisten ja ei-kotimaisten tutkijoiden yhteistyössä tekemää. Tämä huomio selittynee osittain sillä, että fennistiikassa yhteisjulkaiseminen on verraten uusi tieteen tekemisen muoto. Lisäksi havaintoa selittänee toisaalta se, että suomen kielen morfofonologisten ominaispiirteiden vuoksi vertaileva tutkimus ei ole ollut aina mahdollista, ja toisaalta se, että murteentutkimuksen historia ja maine kansallisena tieteenä ovat vaikuttaneet vertailevan kansainvälisen tutkimuksen määrään.

Lähdetietokannasta on mahdollista tarkastella myös ei-kotimaisten tekijöiden edustuksen kehitystä. Kuvio 7 esittää ristiintaulukoinnin perusteella laaditun käyrän ei-kotimaisten tekijöiden prosentuaalisen osuuden kehityksestä.

17. Kategoria "ei tiedossa" tarkoittaa tekijää, jonka kansallisuutta ei ole merkitty aineistoon, "molempia" sen sijaan yksittäiseksi tekijäksi merkittyä tekijäyhdistelmää, jossa on sekä kotimaisia että eikotimaisia tekijöitä. 


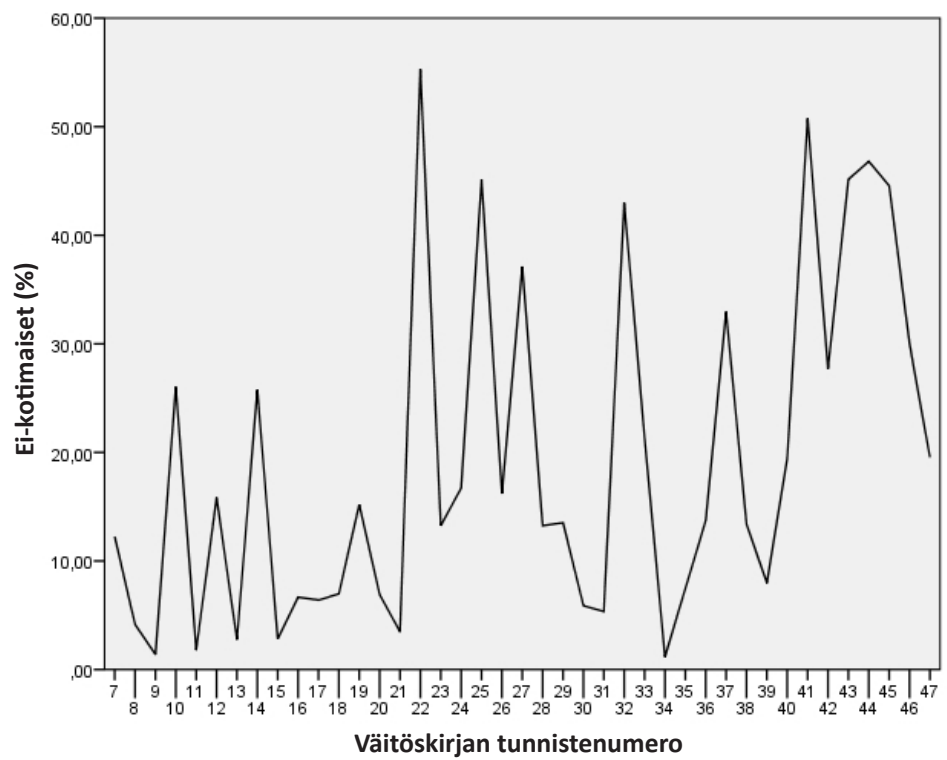

Kuvio 7.

Ei-kotimaisten tekijöiden prosentuaalisen edustuksen kehitys.

Kuvio 7 osoittaa, että väitöskirjojen välillä on huomattavaa variaatiota ei-kotimaisten tekijöiden edustuksessa: 1,2 prosentista (väitöskirja 34 [1993]) 56,6 prosenttiin (väitöskirja 22 [1984]).

\subsection{Nimikkeet}

Tässä alaluvussa tarkastelen lähdetietokannan nimiketietoja selvittääkseni, mihin teoksiin murteita käsittelevissä väitöskirjoissa viitataan eniten. Lähdetietokannassa viitataan 5520 eri nimikkeeseen (tietokannan rivejä yht. 9 783). Taulukkoon 7 on merkitty myös se, miten moneen nimikkeeseen viitataan noin neljäsosassa väitöskirjoja ( $\geq 10$ kertaa) ja miten moneen noin puolessa ( $\geq 20$ kertaa).

Taulukko 7.

Koonti lähdetietokannan nimiketiedoista.

\begin{tabular}{lc}
\multicolumn{2}{l}{ Lähdetietokannan nimiketiedot } \\
\hline Lähderivejä & 9783 \\
\hline $\begin{array}{l}\text { Nimikkeettömiä lähde- } \\
\text { rivejä }\end{array}$ & 0 \\
\hline Nimikkeitä & 5520 \\
\hline $\begin{array}{l}\text { Nimikettä, johon viitattu } \\
\geq 10 \text { kertaa }\end{array}$ & 88 \\
\hline $\begin{array}{l}\text { Nimikettä, johon viitattu } \\
\geq 20 \text { kertaa }\end{array}$ & 22 \\
\hline
\end{tabular}


Toisin kuin tekijädata nimikedata ei ole vinoutunutta: jokaisen väitöskirjan lähdeluettelossa viitataan pääsääntöisesti vain kerran yhteen nimikkeeseen.

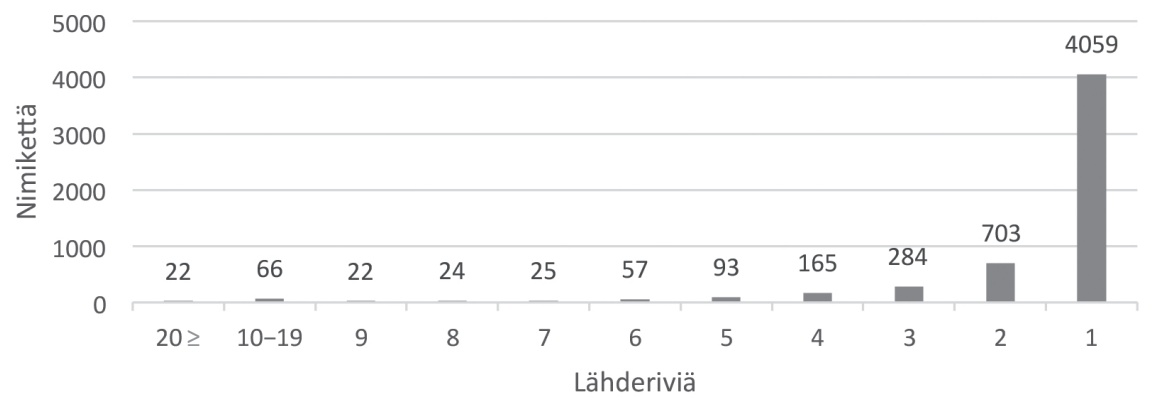

Kuvio 8.

Teosten edustus lähteittäin ( $\mathrm{N}=5$ 520).

Kuten kuviosta 8 on mahdollista havaita, tekijätarkastelun tavoin nimiketarkastelussa hahmottuu tietty peruspiirre: eniten viitattuja teoksia - siis teoksia, joihin viitataan vähintään kymmenen kertaa (noin neljäsosassa väitöskirjoja) - on 5520 nimikkeen joukosta murto-osa, vain 88 . Kuviossa 9 on eritelty tarkemmin viitatuimman 88 nimikkeen joukko.

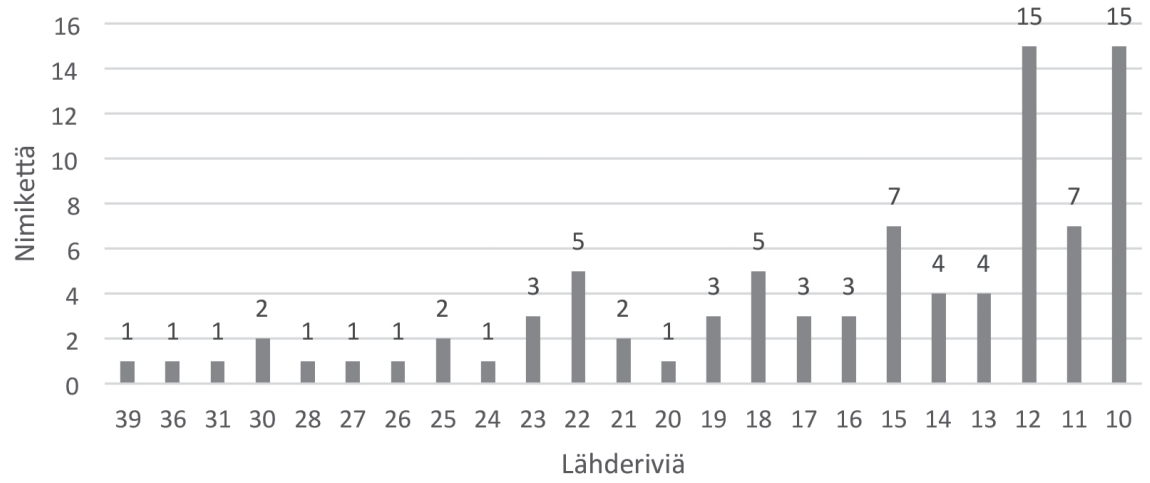

Kuvio 9.

Niiden nimikkeiden määrä, joilla on lähdetietokannassa kymmenen riviä tai enemmän $(\mathrm{N}=88)$.

Taulukkoon 8 olen koonnut ne 22 nimikettä, joihin viitataan noin puolessa väitöskirjoista eli yli 20 kertaa. Frekvenssien suora tarkastelu tuottaa samanlaisen vanhempaa tutkimusta suosivan painotuksen kuin tekijätarkastelussa. Tätä vinoumaa olen pyrkinyt korjaamaan laskemalla suhdeluvun, joka kuvaa lähderivien keskimääräistä määrää kalenterivuosittain viitattavan nimikkeen ilmestymisvuoteen suhteutettuna (ks. taulukon viimeinen sarake). Suhdeluvun laskentakaava on siis [2011 - nimikkeen julkaisuvuosi] / lähdemäärä, jossa 2011 on viimeisten aineistoni väitöskirjojen (46 \& 47) julkaisuvuosi. Mitä korkeampi suhdeluku on, sitä useammin nimikkeeseen on vii- 
tattu sen ilmestymisen jälkeen. Jos nimikkeet asetettaisiin järjestykseen puolestaan pelkän suhdeluvun perusteella, kääntyisi asetelma toisin päin: viitatuimman nimikkeen johtopaikkaa pitäisi Virittäjässä vuonna 2010 ilmestynyt artikkeli "Hämäläisten laulu" (Yli-Luukko 2010), johon viitataan molemmissa vuoden 2010 jälkeen ilmestyneissä väitöskirjoissa (46 [2011] ja 47 [2011]) ja jonka suhdeluku on siksi kaksi. Olen siis valinnut tässä artikkelissa määrittelytavan, jossa viitatuimpien nimikkeiden järjestys perustuu nimikkeiden frekvenssiin, mutta olen täydentänyt tietoa myös nimikkeiden ilmestymisvuoteen suhteutetulla suhdeluvulla.

Taulukko 8.

Lähdetietokannan frekventeimmät nimikkeet, lähderivimäärät sekä nimikkeen julkaisuvuoteen suhteutettu keskimääräinen ilmenemismäärä kalenterivuosittain.

\begin{tabular}{|c|c|c|c|}
\hline Nimike (tekijä) & Julkaisuvuosi & Lähderiviä & $\begin{array}{l}\text { Lähderiviä/ } \\
\text { kalenterivuosi }\end{array}$ \\
\hline $\begin{array}{l}\text { Suomen kielen rakenne ja kehitys } 1 . \\
\text { Äänne- ja muoto-oppia (Hakulinen) }\end{array}$ & 1941 & 39 & 0,56 \\
\hline $\begin{array}{l}\text { Suomen murteet. III. A. Murrekartasto } \\
\text { (Kettunen) }\end{array}$ & 1940 & 36 & 0,51 \\
\hline $\begin{array}{l}\text { Suomen murteet. III. B. Selityksiä murre- } \\
\text { kartastoon (Kettunen) }\end{array}$ & 1940 & 31 & 0,44 \\
\hline $\begin{array}{l}\text { Suomen kielen äännehistorian luennot. } \\
\text { Martti Rapolan kirjallinen tuotanto } \\
\text { (Rapola) }\end{array}$ & 1966 & 30 & 0,67 \\
\hline $\begin{array}{l}\text { Suomen murteet. II. Murrealueet } \\
\text { (Kettunen) }\end{array}$ & 1930 & 30 & 0,37 \\
\hline $\begin{array}{l}\text { Itäisten savolaismurteiden äännehistoria } \\
\text { (Turunen) }\end{array}$ & 1959 & 28 & 0,54 \\
\hline $\begin{array}{l}\text { Äännehistoriallinen tutkimus Etelä- } \\
\text { Pohjanmaan murteesta. I. Konsonantit } \\
\text { (Laurosela) }\end{array}$ & 1913 & 27 & 0,28 \\
\hline Johdatus suomen murteisiin (Rapola) & 1947 & 26 & 0,41 \\
\hline $\begin{array}{l}\text { Äännehistoriallinen tutkimus Tornion } \\
\text { murteesta. Murteen suhdetta suomen } \\
\text { muihin murteihin silmälläpitäen (Airila) }\end{array}$ & 1912 & 25 & 0,25 \\
\hline $\begin{array}{l}\text { Suomen lounaismurteiden äännehistoria. } \\
\text { Vokaalioppi. Descendentti esitys (Ojansuu) }\end{array}$ & 1901 & 25 & 0,23 \\
\hline Kieli ja sen tutkimus (E. Itkonen) & 1966 & 24 & 0,53 \\
\hline $\begin{array}{l}\text { Kaakkois-Hämeen murteiden äänne- } \\
\text { historia. I. Konsonantisto (Lindén) }\end{array}$ & 1942 & 23 & 0,33 \\
\hline Vatjan kielen äännehistoria (Kettunen) & 1915 & 23 & 0,24 \\
\hline $\begin{array}{l}\text { Ala-Satakunnan murteen äännehistoria I. } \\
\text { Descendentti esitys myöhäiskanta- } \\
\text { suomalaisten konsonanttien kehityksestä } \\
\text { (lkola) }\end{array}$ & 1925 & 23 & 0,27 \\
\hline $\begin{array}{l}\text { Äyrämöismurteiden äännehistoria } \\
\text { (Ruoppila) }\end{array}$ & 1955 & 22 & 0,39 \\
\hline $\begin{array}{l}\text { Länsiyläsatakuntalaisten murteiden } \\
\text { äännehistoria. I. Konsonantit (Virtaranta) }\end{array}$ & 1946 & 22 & 0,34 \\
\hline
\end{tabular}


AARIKKA Murteiden tutkimus väitöskirjojen viitteiden valossa

\begin{tabular}{|c|c|c|c|}
\hline $\begin{array}{l}\text { Suomen murteet. I. Murrenäytteitä } \\
\text { (Kettunen) }\end{array}$ & 1930 & 22 & 0,27 \\
\hline $\begin{array}{l}\text { Kantasuomalaiset pääpainottomain } \\
\text { tavujen i-loppuiset diftongit suomen } \\
\text { murteissa (Rapola) }\end{array}$ & 1919 & 22 & 0,24 \\
\hline $\begin{array}{l}\text { Suomen lounaismurteiden äännehistoria. } \\
\text { Konsonantit. Descendentti esitys (Ojan- } \\
\text { suu) }\end{array}$ & 1903 & 21 & 0,2 \\
\hline $\begin{array}{l}\text { Descendenttis-äännehistoriallinen katsaus } \\
\text { Keski-Skandinavian metsäsuomalaisten } \\
\text { kieleen (Kettunen) }\end{array}$ & 1909 & 21 & 0,2 \\
\hline $\begin{array}{l}\text { Äännehistoriallinen tutkimus Etelä- } \\
\text { Pohjanmaan murteesta. II. Vokaalit } \\
\text { (Laurosela) }\end{array}$ & 1914 & 20 & 0,22 \\
\hline $\begin{array}{l}\text { Proto-Finnic final consonants. Their his- } \\
\text { tory in the Finnic languages with particu- } \\
\text { lar reference to the Finnish dialects. I:1. } \\
\text { Introduction. The history of -k in Finnish } \\
\text { (T. Itkonen) }\end{array}$ & 1965 & 20 & 0,43 \\
\hline
\end{tabular}

Kuten taulukosta 8 voi nähdä, eniten lähderivejä on Lauri Hakulisen Suomen kielen rakenne ja kehitys -teoksella (1941). Vaikka aikaisemmin mainitsin, että jokaisessa lähdeluettelossa viitataan teokseen pääsääntöisesti vain kerran, on tämä lähdetietokannan eniten viitatuin nimike tähän sääntöön poikkeus. Väitöskirjassa 24 (1987) viitataan kyseiseen nimikkeeseen neljä kertaa - erikseen neljään eri painokseen. Tämä on kuitenkin poikkeuksellista. Tämän anomalian vuoksi Suomen kielen rakenne ja kehitys -teoksen ykköspaikan voi kuitenkin kyseenalaistaa, sillä siihen ei viitata 11 väitöskirjassa. Kettusen Suomen murteet III A -teokseen (1940) viitataan sen julkaisuvuoden jälkeen ilmestyneistä väitöskirjoista kaikissa paitsi kolmessa (32 [1992], 40 [2003] ja 44 [2009]).

On perusteltua väittää, että taulukon 8 teokset ovat keskeisiä suomalaisessa murteentutkimuksessa. Karlsson (1994: 13-16) esittää omassa sitaatioanalyysissaan 44 eniten lähteenä käytettyä nimikettä ( $>5$ lähdeviiteriviä), joista 8 on samoja teoksia kuin taulukossa 8 esitetyt (suluissa sijoitus / sitaatioiden määrä): Suomen kielen rakenne ja kehitys (1/60), Suomen murteet I-III (3/24), Suomen kielen äännehistorian luennot (8/16), Kieli ja sen tutkimus (5/18) sekä Länsiyläsatakuntalaisten murteiden äännehistoria I-II (24/8). Näiden nimikkeiden kohdalla voidaankin perustellusti puhua koko tieteenalalle merkittävistä teoksista.

Lopuksi on kuitenkin huomattava, että frekvenssiperusteinen tarkastelu aiheuttaa vanhojen nimikkeiden painottumisen: uusimmat taulukossa 8 mainituista eniten viitatuista nimikkeistä ovat ilmestyneet vuonna 1966 (E. Itkonen 1966; Rapola 1966). Kuitenkin Kettusen Suomen murteet -teossarjan tapauksessa varhainen ilmestymisajankohta ei yksin selitä sen runsasta käyttöä lähdekirjallisuutena. Myös Karlssonin julkaisussa, jonka aineiston aikajänne on suppeampi (1/1981-1/1993), Suomen murteet IIII on järjestyksessä kolmanneksi eniten lähteenä käytetty nimike. Kyseessä todella on paitsi murteentutkimuksen myös koko fennistiikan keskeinen teossarja.

Aineistoni 22 viitatuimmasta nimikkeestä jopa 13 käsittelee jollakin tapaa äännehistoriaa. Kun tarkasteluun ottaa nimikkeet, joihin on viitattu noin neljäsosassa väitös- 
kirjoja (88 kpl), on joukko vähemmän homogeeninen. Myös yhdistelemällä frekvenssin ja julkaisuvuoteen suhteutetun suhdeluvun tarjoamia tietoja aineistosta on mahdollista rajata erilaisia perusteltuja kombinaatioita siitä, mitkä nimikkeet ovat fennistisen murteentutkimuksen tutkimushistoriassa keskeisiä. Lopuksi on mainittava vertailun kannalta kiinnostava seikka: Karlssonin (1994) Virittäjä-datan eniten lähteenä käytetyissä 44 nimikkeessä on 15 teosta, jotka Karlsson (mts. 16) luokittelee äännehistorioiksi. Virtarannan länsiyläsatakuntalaisen äännehistorian ja Rapolan äännehistorian luentojen lisäksi hänen analyysissaan esiintyvät 13 äännehistoriaa ovat eri teoksia kuin tämän artikkelin aineiston eniten lähteinä käytetyt nimikkeet.

\subsection{Julkaisuvuodet}

Kolmas tämän artikkelin tarkastelunäkökulma lähdetietokanta-aineistoon on nimikkeiden julkaisuvuosien jakautuminen. Tässä alaluvussa tarkastelen siis sitä, mitkä julkaisuvuodet ovat lähdetietokannassa painottuneita. Taulukkoon 9 on koottu lähteiden julkaisuvuositietoja kuvailevat luvut.

Taulukko 9.

Koonti lähdetietokannan julkaisuvuositiedoista.

\begin{tabular}{lc}
\multicolumn{2}{l}{ Lähdetietokannan julkaisuvuositiedot } \\
\hline Lähderivejä & 9783 \\
\hline $\begin{array}{l}\text { Vuosiluvuttomia lähde- } \\
\text { rivejä }\end{array}$ & 71 \\
\hline $\begin{array}{l}\text { Vuosiluvullisia lähde- } \\
\text { rivejä }\end{array}$ & 9712 \\
\hline
\end{tabular}

Kuten taulukosta 9 käy ilmi, vuosiluvuttomia lähderivejä on 71 kappaletta. Lähderivien vuosiluvuttomuus johtuu pääasiassa siitä, että lähdeluetteloissa viitataan käsikirjoituksiin, joiden julkaisu- tai kirjoitusvuosi ei ole selvillä niiden vanhuuden tai uutuuden vuoksi.

Kuviossa 10 on esitetty lähteiden jakautuminen vuosittain ajanjaksolle, jonka määrittää viitattujen nimikkeiden julkaisuvuodet. Vanhin lähdetietokannan nimike on ilmestynyt vuonna 1540 ja uusin vuonna 2010. Kuten kuviosta voi huomata, 1950-luvun lopulla julkaistujen lähteiden määrä lähtee nousuun ja on runsainta 1970-1980-luvuilla. Kuvion sahalaitaisuus tuo esiin sen, että jokaisella vuosikymmenellä on vuosia, joina on ilmestynyt enemmän lähteitä kuin toisina. Vuosiin 1930 ja 1940 sijoittuvat noin sadan lähderivin piikit selittynevät osittain nimiketarkastelussa erottuneilla, useassa väitöskirjassa lähteinä käytetyillä Lauri Kettusen Suomen murteet I: Murrenäytteitä, Suomen murteet III A: Murrekartasto ja Suomen murteet III B: Selityksiä murrekartastoon -teoksilla, jotka ovat ilmestyneet vuosina 1930 ja 1940. 


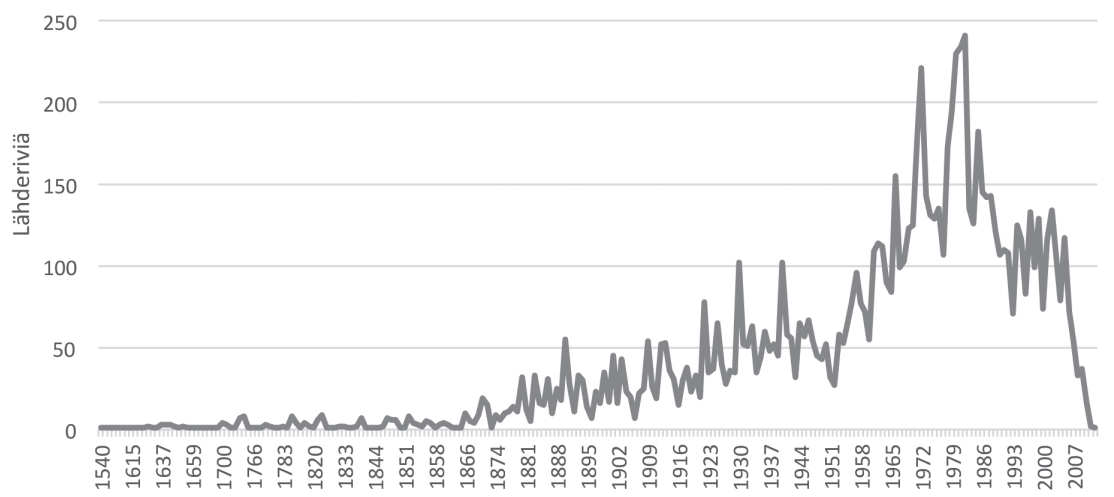

Kuvio 10.

Tietokannan lähteiden määrä julkaisuvuoden perusteella.

Koska aikaskaala viitattujen nimikkeiden välillä on valtava, lähes kuusisataa vuotta, olen kuviossa 11 erottanut vanhimmat nimikkeiden julkaisuvuodet laajemmiksi kategorioiksi. Käytin vedenjakajana vuotta 1809 , jona Suomi siirtyi Ruotsin vallan alta osaksi Venäjää. Myös julkaisuvuodet 1810-1869 esitän laajempana kokonaisuutena. Ensimmäinen aineistoni murreväitöskirja on ilmestynyt vuonna 1871 (ks. taulukkoa 1), ja siksi vuodesta 1870 eteenpäin lähderivien määrä on esitetty vuosikymmenittäin.

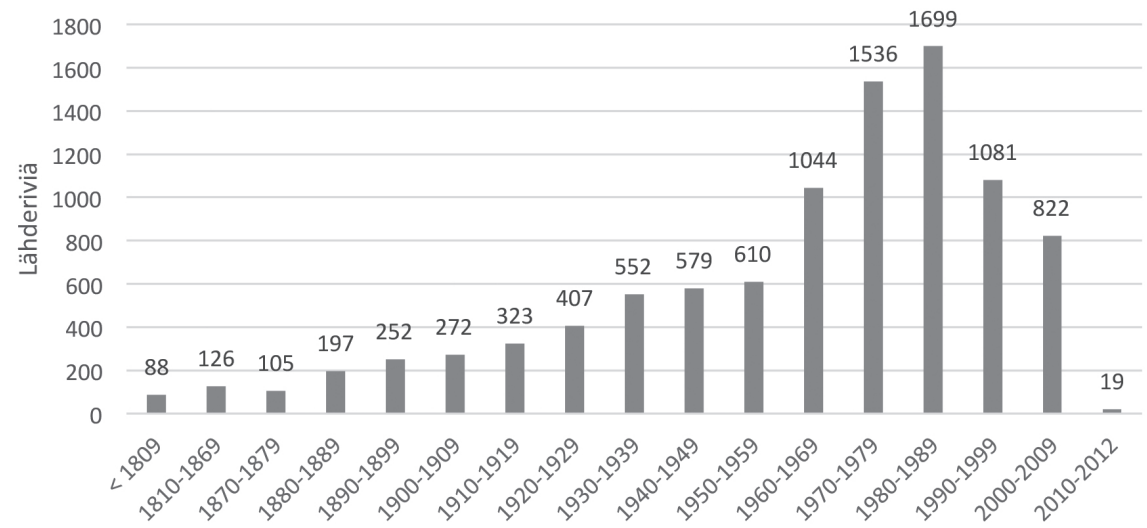

Kuvio 11.

Julkaisuvuosien frekvenssi lähdetietokannassa ennen vuotta 1809, 1810-1869 ja

1870-luvulta lähtien vuosikymmenittäin.

Kuvio 11 havainnollistaa selkeämmin saman, mitä kuvion 10 yhteydessä mainitsin: lähdetietokannassa painottuvat julkaisuvuodet 1970-1989, ja noin puolet lähteistä ajoittuu vuosille 1960-1999. Kun verrataan julkaisuvuosien jakautumista nimiketarkasteluun (alaluku 6.2), voi perustellusti todeta, että 1900-luvun loppupuolella ilmestyneisiin teoksiin viittaaminen on heterogeenisempää kuin vuosisadan alkupuolella ilmestynei- 
siin. Toisin sanoen vuosisadan alkuvuosikymmeninä lähdeluetteloihin on merkitty tyypillisesti tiettyjen nimikkeiden joukko, kun taas vuosisadan loppupuolella lähdeluettelot ovat heterogeenisempiä, jolloin vuosikymmenen edustus julkaisuvuosittain tarkasteltuna painottuu, mutta nimikelähtöisessä tarkastelussa välittömään kärkeen ei valikoidu usein viitattuja nimikkeitä. Toisaalta on myös huomattava, että 17 väitöskirjaa niistä 41 väitöskirjasta, joiden lähdeluetteloista lähdetietokanta on koostettu, on ilmestynyt vuosina 1970-199o (ks. taulukkoa 2), mikä vaikuttanee kyseisten vuosikymmenten painottumiseen lähdetietokanta-aineistossa.

\section{Tulosten koonti ja jatkotutkimuksen aiheita}

Olen tarkastellut tässä artikkelissa suomen murteita käsittelevien väitöskirjojen lähdeluetteloista koostettua lähdetietokantaa tekijä-, nimike- ja julkaisuvuositietojen näkökulmasta. Tarkasteluni on bibliografinen ja perustuu itse laatimaani tietokantaan, jossa on koottuna 41 väitöskirjan lähdeluettelot 9783 tietokantariviksi.

Viitatuin sadasosa eli prosentti tekijöistä kattaa 27 tutkijaa, joihin on viitattu lähdetietokannassa 40-316 kertaa. Yhteensä tähän tekijäjoukkoon viitataan lähdetietokantaaineistossa 2672 kertaa. Yli 10 kertaa lähdeluetteloissa mainittuja tekijöitä on 150. Miesten tekemään tutkimukseen viitataan useammin kuin naisten ja kotimaisten tutkijoiden tekemään tutkimukseen useammin kuin ei-kotimaisten. Tarkastelemissani murteita käsittelevissä väitöskirjoissa ei viitata juuri lainkaan tutkimukseen, joka olisi kotimaisten ja ei-kotimaisten tutkijoiden yhteistyössä tekemää. Sekä tekijöiden sukupuolen että kotimaisuuden näkökulmasta on havaittavissa paitsi laaja väitöskirjakohtainen vaihtelu myös tendenssi kohti kansainvälistymistä ja naisten tasavertaisempaa edustusta tutkimusalalla. Sekä kansainvälistymisen että sukupuolten edustuksen laadullinen jatkoanalysointi olisi tarpeellista ja kiinnostavaa. Oletettavaa on, että väitöskirjakohtainen variaatio lähderivien kotimaisuudessa selittyy vähintään osittain sillä, mikä on väitöskirjan keskeinen tutkimuskohde ja miten yleiskielitieteellinen tai fennistinen tutkimusaihe on.

Aineiston kumulatiivinen luonne aiheuttaa vanhojen nimikkeiden painottumisen. Tämä näkyy esimerkiksi siitä, että uusimmat pelkän frekvenssin perusteella viitatuimmiksi määritetyt teokset ovat ilmestyneet vuonna 1966. Tätä vinoutumista voi tasapainottaa tarkastelemalla viitattujen nimikkeiden julkaisuvuoteen suhteutettua suhdelukua. Joukko on vähemmän homogeeninen myös silloin, kun tarkasteluun ottaa nimikkeet, joihin on viitattu neljäsosassa väitöskirjoja ( $88 \mathrm{kpl})$.

Julkaisuvuoden perusteella lähdetietokantaa tarkasteltaessa voi huomata, että lähdeluetteloista ja siten tietokannasta löytyvien teosten määrä lähtee nousuun 1950-luvun lopulla ja on heterogeenisintä ja runsainta 1970-1980-luvuilla. Noin puolet lähdetietokannan nimikkeistä on julkaistu vuosina 1960-1999.

Julkaisuvuosien ja nimikkeiden jakautumista verrattaessa voi perustellusti todeta, että 1900-luvun loppupuoliskolla ilmestyneisiin nimikkeisiin viittaaminen on heterogeenisempää kuin vuosisadan alkupuoliskon tuotantoon. Toisin sanoen vuosisadan alkuvuosikymmenen nimikkeistä viitataan hyvin spesifiin joukkoon, kun taas vuosisadan loppupuolella ilmestyneistä teoksista viitataan hyvin moneen nimikkeeseen. 
Tällöin 1900-luvun loppuvuosikymmenten edustus julkaisuvuosittain tarkasteltuna painottuu, mutta nimikelähtöisessä tarkastelussa välittömään kärkeen ei valikoidu 1900-luvun loppuvuosikymmeninä ilmestyneitä nimikkeitä. Tätä selittävät paitsi tutkimuksen monimuotoistuminen myös sen määrän kasvu.

Määrällinen tiettyyn alaan kuuluvien väitöskirjojen lähdeluetteloiden tarkasteleminen tuo uuden näkökulman tutkimushistorian analysointiin. Se todentaa empiirisesti, keihin ja mihin tutkimuksiin tieteenalalla viitataan. Kvantitatiivisen luonteen vuoksi näkökulma kuitenkin tarjoaa paljon lisäkysymyksiä ja suoranaisia vaateita laadulliselle jatkotutkimukselle. Yhtenä esimerkkinä tällaisesta vaatimuksesta on äännehistoriaa käsittelevien lähteiden edustus tietokannan viitatuimpien nimikkeiden joukossa. Äännehistorioita on tehty fennistiikan alalla erittäin paljon: aineistohaku Turun yliopiston kirjaston Volter-tietokannasta sanalla äännehistoria tuottaa 160 hakutulosta. Miksi lähdetietokannassa juuri tietyt 14 äännehistoriaa käsittelevää nimikettä ovat lähdetietokannan viitatuimpien joukossa?

Myös tekijätarkastelun osalta sama kanonisoitumisen mysteeri on ratkaisematta. Fennistiikan historia, kuten minkä tahansa tutkimusalan historia, on täynnä tarinoita vastustusta aiheuttaneista tutkijoista ja heidän ajatuksistaan, jotka historian saatossa ovat saaneet niin sanotun kunnianpalautuksen (tunnetuimmat esimerkit kenties Arvid Genez ja Lauri Kettunen, mutta myös esim. Ahti Rytkönen [Tainio 1995]). Kuten mainitsin luvussa 5 , lähdetietokanta ei sinällään kerro mitään viittauksien laadusta: onko tekijään tai nimikkeeseen viitattu samanmielisyyttä vai erimielisyyttä osoittaen? Väitteeni on, ettei viittauksien laadulla ole välttämättä merkitystä. Vaikka teos tai henkilö herättää julkilausuttua vastustusta, hänen paikkansa tieteenalan kaanonissa silti vahvistuu. Lähdetietokannan yksi merkittävimpiä anteja onkin se, mitä ja keitä siitä ei löydy. On tutkijoita ja tutkimuksia - ajattelijoita ja ajatuksia -, jotka marginalisoituvat eivätkä vakiinnu tieteenalan kaanoniin. Se on tieteen kehityksen kannalta kiinnostavaa ja merkittävää.

Tässä tarkastelemieni näkökulmien lisäksi kokoamani lähdetietokanta-aineisto tarjoaa lukemattomia mahdollisuuksia sekä kvantitatiiviselle että kvalitatiiviselle tarkastelulle. Olen omassa jaottelussani jakanut tekijät kansallisuuden perusteella vain kahteen joukkoon: kotimaisiin ja ei-kotimaisiin. Erityisesti ei-kotimaisten tekijöiden joukkoa olisi mahdollista analysoida laadullisesti tarkemmin ja selvittää, onko murteentutkimuksen kansainvälisten viittauksien laatu muuttunut tutkimushistorian aikana. Aineistosta on mahdollista tyypitellä myös erilaisia lähdejoukkoja, joiden tarkempi analyysi auttaisi ymmärtämään paremmin, miten käsitystä suomalaisesta kielestä ja kulttuurista on muokattu myös tutkimuksellisin keinoin. Tällaisia lähteitä ovat esimerkiksi maallikoiden ja myös tutkijoiden laatimat murrekirjat ja toisaalta kaunokirjalliset teokset. Erityisesti kirjasuomen ja suomen kielen kielioppien historiaan perehtyneitä fennistejä puolestaan saattaisi kiinnostaa, mitä sanakirjoja, oppikirjoja ja varhaisimpia suomenkielisiä kirjallisia lähteitä murteentutkimuksessa on hyödynnetty ja miten. Yhtenä lähteiden osajoukkona erottuvat myös mielipidekirjoitukset ja muut lehtikirjoitukset. Murteet ovat aihe, joka puhuttaa lehtien palstoilla yhä edelleen. Myös tätä julkisen keskustelun suhdetta murteiden tutkimukseen olisi mielenkiintoista tarkastella lähemmin. Näihin ja muihin mahdollisiin tutkimusaiheisiin lähdetietokanta on muiden tutkijoiden hyödynnettävissä tämän artikkelin julkaisemisen jälkeen. 


\section{Lähteet}

\section{Aineslähteet}

Airila, Mart ti 1912: Ä̈nnehistoriallinen tutkimus Tornion murteesta. Murteen suhdetta suomen muihin murteihin silmälläpitäen. Helsinki.

Aminoff, Torsten Gustav 1871: Etelä-Pohjanmaan kielimurteesta tutkimus. Helsinki.

Cannelin, Knut 1888: Tutkimus Kemin kielenmurteesta. Helsinki: Suomalaisen Kirjallisuuden Seura.

Forsberg, Hannele 1998: Suomen murteiden potentiaali. Muoto ja merkitys. SKST 720. Helsinki: Suomalaisen Kirjallisuuden Seura.

Genetz, Arvid 1877: Lautphysiologische Einführung in das Studium der vestfinnischen Sprachen mit besonderer Berücksichtigung des Karelischen. Helsinki.

Grönholm, Maija 1988: Ruotsalaiset lainasanat Turun murteessa. Turku: Åbo Akademis förlag.

Hurtta, Heik ri 2000: Suomen murteiden askel-tyyppisten nominien morfologiaa ja murremaantiedettä. Opera fennistica \& linguistica 9. Tampere: Tampereen yliopiston suomen kielen ja yleisen kielitieteen laitos.

Iкоla, Niılo 1925: Ala-Satakunnan murteen äännehistoria I. Descendentti esitys myöhäiskantasuomalaisten konsonanttien kehityksestä. Turun yliopiston julkaisuja. Sarja B, osa 3, nro 1. Turku: Turun yliopiston julkaisuja.

It konen, Terho 1965: Proto-Finnic final consonants. Their history in the Finnic languages with particular reference to the Finnish dialects. I:1. Introduction. The history of -k in Finnish. Suomalais-Ugrilaisen Seuran Toimituksia 138, 1. Helsinki: Suomalais-Ugrilainen Seura.

JARVA, VESA 2003: Venäläisperäisyys ja ekspressiivisyys suomen murteiden sanastossa. Jyväskylä Studies in Humanities 5. Jyväskylä: Jyväskylän yliopisto.

JUUSElA, KAISU 1989: Törmäysmurteen variaatiosta. Jälkitavun i-loppuisen diftongin edustus Töysän murteessa. SKST 496. Helsinki: Suomalaisen Kirjallisuuden Seura.

KoIvisto, Jouko 1990: Suomen murteiden refleksiivitaivutus. SKST 532. Helsinki: Suomalaisen Kirjallisuuden Seura.

Кокко, Ossi 2007: Inkerinsuomen pirstaleisuus. Eräiden sijojen kehitys murteen yksilöllistymisen kuvastajana. Joensuun yliopiston humanistisia julkaisuja 48. Joensuu: Joensuun yliopisto.

Krook, KristinnA 1999: Ensi tavun ie-, yö- ja uo-diftongien avartuminen suomen murteissa. Turun yliopiston suomalaisen ja yleisen kielitieteen laitoksen julkaisuja 62. Turku: Turun yliopisto.

Kuiri, KaIja 1984: Referointi Kainuun ja Pohjois-Karjalan murteissa. SKST 405. Joensuun yliopiston humanistisia julkaisuja 2. Helsinki: Suomalaisen Kirjallisuuden Seura.

Kunnas, NiIna 2007: Miten muuttuu runokylien kieli. Reaaliaikatutkimus jälkitavujen Aloppuisten vokaalijonojen variaatiosta vienalaismurteissa. Acta Universitatis Ouluensis. B, Humaniora 78. Oulu: Oulun yliopisto, suomen kielen, informaatiotutkimuksen ja logopedian laitos.

KURKI, Toмmi 2005: Yksilön ja ryhmän kielen reaaliaikainen muuttuminen. Kielenmuutosten seuraamisesta ja niiden tarkastelussa käytettävistä menetelmistä. SKST 1036. Helsinki: Suomalaisen Kirjallisuuden Seura.

LAITINEN, LEA 1992: Välttämättömyys ja persoona. Suomen murteiden nesessiivisten rakenteiden semantiikkaa ja kielioppia. SKST 569. Helsinki: Suomalaisen Kirjallisuuden Seura.

Laurosela, Jussi 1913: Äännehistoriallinen tutkimus Etelä-Pohjanmaan murteesta. I. Konso- 
nantit. Helsinki: Suomalaisen Kirjallisuuden Seura.

Leнtimäki, PekкA 1972: Oi- ja ei-nominit Länsi-Uudenmaan murteissa. SKST 310. Helsinki: Suomalaisen Kirjallisuuden Seura.

LeSKINEN, HeIK KI 1963: Luoteis-Laatokan murteiden äännehistoria. I. Konsonantit. SKST 275. Helsinki: Suomalaisen Kirjallisuuden Seura.

Lindén, Eeva 1942: Kaakkois-Hämeen murteiden äännehistoria. I. Konsonantisto. SKST 219. Helsinki: Suomalaisen Kirjallisuuden Seura.

LäNSIMÄKI, MAIJA 1987: Suomen verbikantaiset in : ime -johdokset. SKST 469. Helsinki: Suomalaisen Kirjallisuuden Seura.

MANTILA, HARri 1992: Ei tääläkhän senthän jokhaishen sanhan hootakhan panna. Jälkitavujen vokaalienvälisen h:n variaatio peräpohjalaisissa murteissa. SKST 572 . Helsinki: Suomalaisen Kirjallisuuden Seura.

Mielikäinen, Aila 1981: Etelä-Savon murteiden äännehistoria. I. Konsonantit. SKST 375. Helsinki: Suomalaisen Kirjallisuuden Seura.

Mustanoja, LiIs a 2011: Idiolekti ja sen muuttuminen. Reaaliaikatutkimus Tampereen puhekielestä. Acta Universitatis Tamperensis 1605. Tampere: Tampere University Press.

Mäkelä, Matt i 1993: Suomen murteiden kin ja kaan, kään -liitteet. Morfologia ja leksikko. SKST 591. Helsinki: Suomalaisen Kirjallisuuden Seura.

NAнкоLA, KARI 1987: Yleisgeminaatio. Ä̈̈nteenmuutoksen synty ja vaiheet kielisysteemissä erityisesti Tampereen seudun hämäläismurteiden kannalta. SKST 457. Helsinki: Suomalaisen Kirjallisuuden Seura.

NuOlijärvi, Pirkкo 1986: Kolmannen sukupolven kieli. Helsinkiin muuttaneiden suurten ikäluokkien eteläpohjalaisten ja pohjoissavolaisten kielellinen sopeutuminen. SKST 436. Helsinki: Suomalaisen Kirjallisuuden Seura.

Nupponen, Anne-Maria 2011: "Savon murre” savolaiskorvin. Kansa murteen havainnoijana. Publications of the University of Eastern Finland. Dissertations in Education, Humanities and Theology, 11. Joensuu: University of Eastern Finland.

OjajÄRvi, Aulis 1950: Sijojen merkitystehtävistä Itä-Karjalan Maaselän murteissa. Nominatiivi, genetiivi, akkusatiivi ja partitivi. Vertaileva funktio-opillinen tutkimus. SuomalaisUgrilaisen Seuran Toimituksia 97. Helsinki: Suomalais-Ugrilainen Seura.

Ojansuu, Heıк к 1901: Suomen lounaismurteiden äännehistoria. Vokaalioppi. Descendentti esitys. Helsinki: Suomalaisen Kirjallisuuden Seura.

PAlAnder, MARJATta 1987: Suomen itämurteiden erikoisgeminaatio. SKST 455. Helsinki: Suomalaisen Kirjallisuuden Seura.

PALOMÄKi, Ulla 1998: Dentaalisen affrikaatan perilliset suomen murteissa. Kielikontakteihin perustuva selitysmalli. Turun yliopiston suomalaisen ja yleisen kielitieteen laitoksen julkaisuja 59. Turku: Turun yliopisto.

PAUnONen, HeIK Ki 1974: Monikon genetiivin muodostus suomen kielessä. I. Johdanto. Yksivartaloisten kaksitavujen monikon genetiivi suomen murteissa. SKST317. Helsinki: Suomalaisen Kirjallisuuden Seura.

PORKKA, VOLMARI 1885: Über den ingrischen Dialekt mit Berücksichtigung der übrigen finnisch-ingermanländischen Dialekte. Helsinki: Frenckell.

PriIKI, KATRI 2017: Hän, se, tää vai toi? Vuorovaikutussosiolingvistinen tutkimus henkilöviittauksista Kaakkois-Satakunnan nykypuhekielessä. Turun yliopiston julkaisuja, Sarja C, Scripta lingua Fennica edita 432. Turku: Turun yliopisto.

PÄ̈̈ккӧNEn, Matт т 1971: Oulun seudun murteen äännehistoria. I. Sanansisäiset klusiilit astevaihtelusuhteineen. SKST 289. Helsinki: Suomalaisen Kirjallisuuden Seura. 
Rapola, Mart ti 1919: Kantasuomalaiset pä̈painottomain tavujen i-loppuiset diftongit suomen murteissa. Helsinki: Suomalaisen Kirjallisuuden Seura.

Rıntala, Päıvi 1972: Suomen -läntä-loppuiset adjektiivit. SKST 306. Helsinki: Suomalaisen Kirjallisuuden Seura.

Ruop pila, VeI ko 1943: Kotieläinten nimitykset Suomen murteissa. I. Hevonen, nauta, lammas, vuohi. SKST 222. Helsinki: Suomalaisen Kirjallisuuden Seura.

RÄISÄNEN, Alpo 1972: Kainuun murteiden äännehistoria. I. Vokaalisto. SKST 307. Helsinki: Suomalaisen Kirjallisuuden Seura.

RÄSÄNEn, SEPPo 1972: Kainuun murteiden kaasussyntaksi. SKST 308. Helsinki: Suomalaisen Kirjallisuuden Seura.

SivUl A, JA A K KO 1989: Lintu soidessa sokea. Suomen murteiden kiimatermistö. SKST 504. Helsinki: Suomalaisen Kirjallisuuden Seura.

Suihronen, PaAvo 1992: Klusiilien vaihtelusuhteet Kala- ja Lestijokilaakson murteissa. SKST 577. Helsinki: Suomalaisen Kirjallisuuden Seura.

Suinkonen, Pent ti 1994: Frekventatividerivaatio suomen murteissa. Morfologis-fonologista tarkastelua. SKST 613. Helsinki: Suomalaisen Kirjallisuuden Seura.

SKST = Suomalaisen Kirjallisuuden Seuran Toimituksia.

VAat tova ARA, Johanna 2009: Meän tapa puhua. Tornionlaakso pellolaisnuorten subjektiivisena paikkana ja murrealueena. SKST 1224. Helsinki: Suomalaisen Kirjallisuuden Seura.

Virtaranta, Pert ti 1946: Länsiyläsatakuntalaisten murteiden ä̈̈nehistoria. I. Konsonantit. SKST 230. Helsinki: Suomalaisen Kirjallisuuden Seura.

VÄÄNÄNEN, MILJA 2016: Subjektin ilmaiseminen yksikön ensimmäisessä persoonassa. Tutkimus suomen vanhoista murteista. Turun yliopiston julkaisuja. Sarja C, Scripta lingua Fennica edita 430. Turku: Turun yliopisto.

YLITALO, RIIKKA 2009: The realisation of prominence in three varieties of standard spoken Finnish. Acta Universitatis Ouluensis. B, Humaniora 88. Oulu: Oulun yliopisto.

\section{Muut lähteet}

Airila, Mart ti 1912: Ä̈̈nnehistoriallinen tutkimus Tornion murteesta. Murteen suhdetta suomen muihin murteihin silmälläpitäen. Helsinki.

Aminoff, Torsten 1871: Etelä-Pohjanmaan kielimurteesta tutkimus. Helsinki.

Haddington, Pentti - Sivonen, Jari (toim.) 2010: Kielentutkimuksen modernit klassikot. Kognitiivinen ja funktionaalinen kielitiede. Helsinki: Gaudeamus.

HAKUlinen, LAURI 1941: Suomen kielen rakenne ja kehitys 1. Ä̈nne- ja muoto-oppia. Helsinki: Otava.

Hovdhaugen, Even - Karlsson, Fred - Henriksen, Carol - Sigurd, Bengt 2000: The history of linguistics in the Nordic countries. Jyväskylä: Gummerus.

Huumo, Katja - Laitinen, Lea - Paloposki, Outi (toim.) 2004: Yhteistä kieltä tekemässä. Näkökulmia suomen kirjakielen kehitykseen 180o-luvulla. Helsinki: Suomalaisen Kirjallisuuden Seura.

Hynönen, Emmi 2016: Suomen essiivi. Turku: Turun yliopisto.

Ḧ̈KKINEN, KAISA 2008: Suomen kielen historia 2. Suomen kielen tutkimuksen historia. Turku: Turun yliopisto.

Iкоla, Niılo 1925: Ala-Satakunnan murteen äännehistoria I. Descendentti esitys myöhäiskantasuomalaisten konsonanttien kehityksestä. Turun yliopiston julkaisuja. Sarja B, osa 3, nro 1. Turku: Turun yliopiston julkaisuja. 
AARIKKA Murteiden tutkimus väitöskirjojen viitteiden valossa

It KONEN, ERKKi 1966: Kieli ja sen tutkimus. Helsinki: WSOY.

It konen, Terho 1965: Proto-Finnic final consonants. Their history in the Finnic languages with particular reference to the Finnish dialects. I:1. Introduction. The history of $-\mathrm{k}$ in Finnish. Suomalais-Ugrilaisen Seuran Toimituksia 138, 1. Helsinki: Suomalais-Ugrilainen Seura.

JUUSELA, KAISU 1994: Variation as a theme in Finnish dialectology and sociolinguistics in recent years. - Fenno-Ugrica Suecana. Tidskrift för finsk-ugrisk forskning i Sverige s. 1-54.

KARLSSON, FRED 1994: Linguistics in the light of citation analysis. Yleisen kielitieteen laitoksen julkaisuja 23. Helsinki: Helsingin yliopisto.

— 1998: Kielitieteiden tohtorinväitöskirjat Suomessa 1840-1997. Yleisen kielitieteen laitoksen julkaisuja 29. Helsinki: Helsingin yliopisto.

— 2000: E. N. Setälä vaarallisilla vesillä. Tieteellisen vallankäytön, käyttäytymisen ja perinteen analyysi. Helsinki: Suomalaisen Kirjallisuuden Seura.

KelomäKi, TAPANi 2009: Nuorgrammaattisuuden myytti suomen kielen tutkimuksessa. Helsinki: Helsingin yliopiston suomen kielen ja kotimaisen kirjallisuuden laitos.

Kettunen, Lauri 1909: Descendenttis-äännehistoriallinen katsaus Keski-Skandinavian metsäsuomalaisten kieleen. Helsinki: Suomalaisen Kirjallisuuden Seura.

— 1915: Vatjan kielen äännehistoria. Helsinki.

— 1930a: Suomen murteet. I. Murrenäytteitä. Helsinki: Suomalaisen Kirjallisuuden Seura.

— 193ob: Suomen murteet. II. Murrealueet. Helsinki: Suomalaisen Kirjallisuuden Seura.

— 1940a: Suomen murteet. III. A. Murrekartasto. Helsinki: Suomalaisen Kirjallisuuden Seura.

— 1940b: Suomen murteet. III. B. Selityksiä murrekartastoon. Helsinki: Suomalaisen Kirjallisuuden Seura.

Knu t tila, Seppo 1994: Tyhmän kansan teoria. Näkökulmia menneestä tulevaan. Helsinki: Suomalaisen Kirjallisuuden Seura.

Korhonen, Miкко 1986: Finno-Ugrian language studies in Finland 1828-1918. The history of learning and science in Finland 1828-1918, 11. Helsinki: Societas Scientiarum Fennica.

Kurki, Tомmi 2007: Variaationtutkimuksen nykynäkymiä. - Sananjalka 49 s. 143-162.

Labov, William 1972: Sociolinguistic patterns. Oxford: Blackwell.

— 2006: The social stratification of English in New York City. Cambridge: Cambridge University Press.

Laurosela, Jussi 1913: Ä̈nnehistoriallinen tutkimus Etelä-Pohjanmaan murteesta. I. Konsonantit. Helsinki: Suomalaisen Kirjallisuuden Seura.

— 1914: Ä̈̈nnehistoriallinen tutkimus Etelä-Pohjanmaan murteesta. II. Vokaalit. Helsinki: Suomalaisen Kirjallisuuden Seura.

LeINO, JA A K KO 2003: Antaa sen muuttua. Suomen kielen permissiivirakenne ja sen kehitys. SKST 9oo. Helsinki: Suomalaisen Kirjallisuuden Seura.

Leino, Pent ti 1992: Fennistiikan tohtorit. - Kielikello 3 s. 13-22.

LINDÉn, EEVA 1942: Kaakkois-Hämeen murteiden äännehistoria. I. Konsonantisto. SKST 219. Helsinki: Suomalaisen Kirjallisuuden Seura.

Mielikäinen, Aila 1980: Johdanto. Nykysuomalaisen puhekielen tutkimuksen taustaa. Aila Mielikäinen (toim.), Nykysuomalaisen puhekielen murros. Jyväskylän osatutkimus. Raportti 1. Jyväskylän ylipiston suomen kielen ja viestinnän laitoksen julkaisuja 20. Jyväskylä: Jyväskylän yliopisto.

Mustanoja, LiIs a 2011: Idiolekti ja sen muuttuminen. Reaaliaikatutkimus Tampereen puhekielestä. Tampere: Tampere University Press.

NuOliJäRvi, PIrkко 1986: Kolmannen sukupolven kieli. Helsinkiin muuttaneiden suurten ikäluokkien eteläpohjalaisten ja pohjoissavolaisten kielellinen sopeutuminen. SKST 436. 
Helsinki: Suomalaisen Kirjallisuuden Seura.

Nuolijärvi, Pirkko - Sorjonen, Marja-Leena 2005: Miten kuvata muutosta? Puhutun kielen tutkimuksen lähtökohtia murteenseuruuhankkeen pohjalta. Kotimaisten kielten tutkimuskeskuksen julkaisuja 133. Helsinki: Kotimaisten kielten tutkimuskeskus.

Ojansuu, Heıкк 1901: Suomen lounaismurteiden ä̈̈nnehistoria. Vokaalioppi. Descendentti esitys. Helsinki: Suomalaisen Kirjallisuuden Seura.

1903: Suomen lounaismurteiden ä̈̈nnehistoria. Konsonantit. Descendentti esitys. Helsinki: Suomalaisen Kirjallisuuden Seura.

Paunonen, Heik i 1971: Sosiolingvistinen metodi ja sen sovellus. (Arvostelu William Labovin teoksesta "The social stratification of New York City”.) - Virittäjä 75 s. 401-412.

_ 2009: Suomalaisen sosiolingvistiikan ja kielisosiologian nykynäkymiä. - Virittäjä 113 s. 557-570.

Pekkarinen, Heli 2011: Monikasvoinen TAVA-partisiippi. Tutkimus suomen TAVA-partisiipin käyttökonteksteista ja verbiliittojen kieliopillistumisesta. Helsinki: Helsingin yliopisto.

PrIIKI, KATRI 2017: Hän, se, tää vai toi? Vuorovaikutussosiolingvistinen tutkimus henkilöviittauksista Kaakkois-Satakunnan nykypuhekielessä. Turun yliopiston julkaisuja, Sarja C, Scripta lingua Fennica edita 432. Turku: Turun yliopisto.

PÄıvı̈̈, PıA 2007: Suomen kielen asti ja saakka. Terminatiivisten partikkelien synonymia, merkitys, käyttö ja kehitys sekä asema kieliopissa. Turun yliopiston suomalaisen ja yleisen kielitieteen laitoksen julkaisuja 75. Turku: Turun yliopisto.

Ra POla, Mart Ti 1919: Kantasuomalaiset pä̈painottomain tavujen i-loppuiset diftongit suomen murteissa. Helsinki: Suomalaisen Kirjallisuuden Seura.

- 1947: Johdatus suomen murteisiin. Helsinki: Suomalaisen Kirjallisuuden Seura. 1966: Suomen kielen äännehistorian luennot. Martti Rapolan kirjallinen tuotanto. SKST 283. Helsinki: Suomalaisen Kirjallisuuden Seura.

Ruoppila, Veıкко 1955: Äyrämöismurteiden äännehistoria. Helsinki: Suomalaisen Kirjallisuuden Seura.

SAlminen, TARU 2000: Morfologiasta moniäänisyyteen. Suomen kielen kvasirakenteen merkitys, käyttö ja kehitys. SKST 796. Helsinki: Suomalaisen Kirjallisuuden Seura.

SirtoneN, Kirsti 1981: Dialektologian ja sosiolingvistiikan suhteesta. - M. K. Suojanen (toim.), Kirjoituksia puhekielestä s. 43-58. Turun yliopiston suomalaisen ja yleisen kielitieteen laitoksen julkaisuja 14. Turun puhekielen projektin julkaisuja 1. Turku: Turun yliopisto.

SKST $=$ Suomalaisen Kirjallisuuden Seuran Toimituksia

Suutari, Toni - Salo, Merja (toim.) 2001: Castrénin perilliset. Helsingin yliopiston suomen ja sen sukukielten professorit 1851-2001. Helsinki: Helsingin yliopiston suomen kielen laitos.

TAINIO, Liıs A 1995: Ahti Rytkönen kielentutkimuksen työmaalla. - Virittäjä 99 s. 437-445.

Tieteen termipankki. http://tieteentermipankki.fi.

Turunen, Aimo 1959: Itäisten savolaismurteiden äännehistoria. Helsinki: Suomalaisen Kirjallisuuden Seura.

Virtaranta, Pert ti 1946: Länsiyläsatakuntalaisten murteiden ä̈nnehistoria. I. Konsonantit. SKST 230. Helsinki: Suomalaisen Kirjallisuuden Seura.

Yli-Luukкo, Eeva 2010: Hämäläisten laulu. Puheen melodinen jaksottaminen. Intonaationtutkimusta 50-vuotiaassa Suomen kielen nauhoitearkistossa. - Virittäjä 114 s. 396-409. 


\section{Dialect study in the light of citations}

This article considers research history on dialects in Finland. It examines the relationship of dialectology and sociolinguistics in the study of dialects and explains why they must be understood as one continuous research history. The data used in this article comes from a citation database compiled from the bibliographies of 41 doctoral theses.

In the citation database, 27 researchers comprise the most cited 1\%; they have been cited between 40 and 316 times. The most cited $1 \%$ has been cited in the database a total of 2,672 times, while 150 individual researchers have been cited over 10 times. Men are cited more often than women, and Finnish researchers have been cited more frequently than non-Finnish ones. There are almost no citations to research that has been conducted jointly by a Finnish and non-Finnish researcher. The variation in citing women and non-Finnish researchers is great, and there is a tendency towards more international and equal citing.

The cumulative nature of the data means that older research is over-represented. This can be deduced from the fact that the newest frequently cited research dates from 1966. This distortion can be balanced by creating and analysing a ratio based on the year in which individual works were published. Also, when looking at the research that has been cited in a quarter of all dissertations (88), the data becomes less homogenous. When analysing the amount of research published, it is justified to say that citing in the late 20 th century is more heterogeneous than it was at the beginning of the century. The diversification and increased volume of research explains this change.

The article demonstrates how a quantitative perspective, based on citations, can enhance our understanding of research history. It verifies with empirical data whom and which research has been cited over the years. Finally, the article concludes what kinds of questions concerning research history arise and can still be answered by further investigating the citation database. 


\section{Murteiden tutkimus väitöskirjojen viitteiden valossa}

Artikkelissa tarkastellaan suomalaisen murteentutkimuksen historiaa suomen kielen alalla ilmestyneiden murteita käsittelevien väitöskirjojen lähdeluetteloiden avulla. Artikkelissa käsitellään dialektologian ja sosiolingvistiikan suhdetta sekä perustellaan sitä, miksi alueellisen vaihtelun tutkimushistoriaa on tarpeen tarkastella kokonaisuutena. Aineistona on 41 väitöskirjan lähdeluetteloista koostettu lähdetietokanta, jota analysoidaan tekijä-, nimike- ja julkaisuvuositietojen näkökulmasta.

Lähdetietokannan viitatuin sadasosa tekijöistä kattaa 27 tutkijaa, joihin on viitattu lähdetietokannassa 40-316 kertaa. Yhteensä tähän tekijäjoukkoon viitataan lähdetietokanta-aineistossa 2672 kertaa. Yli 10 kertaa lähdeluetteloissa mainittuja tekijöitä on 150. Miesten tekemään tutkimukseen viitataan useammin kuin naisten ja kotimaisten tutkijoiden tekemään tutkimukseen useammin kuin ei-kotimaisten. Murteita käsittelevissä väitöskirjoissa ei viitata juuri lainkaan tutkimukseen, joka olisi kotimaisten ja ei-kotimaisten tutkijoiden yhteistyössä tekemää. Sekä tekijöiden sukupuolen että kotimaisuuden näkökulmasta on havaittavissa paitsi laaja väitöskirjakohtainen vaihtelu myös tendenssi kohti kansainvälistymistä ja naisten tasavertaisempaa edustusta tutkimusalalla.

Aineiston kumulatiivinen luonne aiheuttaa vanhojen nimikkeiden painottumisen. Tämä näkyy esimerkiksi siitä, että uusimmat pelkän frekvenssin perusteella viitatuimmiksi määritetyt teokset ovat ilmestyneet vuonna 1966. Tätä vinoutumista voi tasapainottaa tarkastelemalla viitattujen nimikkeiden julkaisuvuoteen suhteutettua suhdelukua. Myös siten, että tarkasteluun ottaa nimikkeet, joihin on viitattu neljäsosassa väitöskirjoja ( $88 \mathrm{kpl}$ ), on joukko vähemmän homogeeninen. Julkaisuvuosien ja nimikkeiden jakautumista verrattaessa voi perustellusti todeta, että 1900-luvun loppupuoliskolla ilmestyneisiin nimikkeisiin viittaaminen on heterogeenisempää kuin vuosisadan alkupuoliskolla ilmestyneisiin. Tätä selittävät paitsi tutkimuksen monimuotoistuminen myös sen määrän kasvu.

Lähdeluetteloiden tarkasteleminen tuo uuden näkökulman tutkimushistorian analysointiin. Se todentaa empiirisesti, keihin ja mihin tutkimuksiin tieteenalalla viitataan. Kvantitatiivisen luonteensa vuoksi näkökulma tarjoaa myös paljon lisäkysymyksiä laadulliselle jatkotutkimukselle.

Kirjoittajan yhteystiedot (address):

etunimi.sukunimi@utu.fi

Kirjoittaja on suomen kielen väitöskirjatutkija Turun yliopistossa. 